NBER WORKING PAPER SERIES

\title{
SAFETY-NET BENEFITS CONFERRED ON DIFFICULT-TO-FAIL-AND-UNWIND BANKS IN THE US AND EU BEFORE AND DURING THE GREAT RECESSION
}

\author{
Santiago Carbo-Valverde \\ Edward J. Kane \\ Francisco Rodriguez-Fernandez \\ Working Paper 16787 \\ http://www.nber.org/papers/w16787
}

\author{
NATIONAL BUREAU OF ECONOMIC RESEARCH \\ 1050 Massachusetts Avenue \\ Cambridge, MA 02138 \\ February 2011
}

The authors thank the Fundación de las Cajas de Ahorros (Funcas) for supporting this research. We also thank James Wilcox, Robert Eisenbeis and other participants in the 2011 ASSA meetings and from Marianne Verdier and other participants in the seminar held at the Université Paris Ouest-Nanterre la Défense in January 2011. Comments from Ethan Cohen-Cole, Robert Dickler, Stephen Kane, and James Thomson are also acknowledged and appreciated. Santiago Carbó and Francisco Rodriguez acknowledge financial support from the Spanish Ministry of Science and Innovation and FEDER (ECO200805243/ECON) and from the Consejería de Innovación, Ciencia y Empresa-Junta de Andalucía (P08-SEJ03781). Kane is grateful for support received on a related project from the Institute for New Economic Thinking. The views expressed herein are those of the authors and do not necessarily reflect the views of the National Bureau of Economic Research.

NBER working papers are circulated for discussion and comment purposes. They have not been peerreviewed or been subject to the review by the NBER Board of Directors that accompanies official NBER publications.

(C) 2011 by Santiago Carbo-Valverde, Edward J. Kane, and Francisco Rodriguez-Fernandez. All rights reserved. Short sections of text, not to exceed two paragraphs, may be quoted without explicit permission provided that full credit, including $(\subset$ notice, is given to the source. 
Safety-Net Benefits Conferred on Difficult-to-Fail-and-Unwind Banks in the US and EU Before and During the Great Recession

Santiago Carbo-Valverde, Edward J. Kane, and Francisco Rodriguez-Fernandez

NBER Working Paper No. 16787

February 2011

JEL No. G01,G2,G21,G28,G38,K2

\section{ABSTRACT}

This paper models and estimates ex ante safety-net benefits at a sample of large banks in US and Europe during 2003-2008. Our results suggest that difficult-to-fail and unwind (DFU) banks enjoyed substantially higher ex ante benefits than other institutions. Safety-net benefits prove significantly larger for DFU firms in Europe and bailout decisions less driven by asset size than in the US. We also find that a proxy for regulatory capture helps to explain bailout decisions in Europe. A policy implication of our findings is that authorities could better contain safety-net benefits if they refocused their information systems on measuring volatility as well as capital.

Santiago Carbo-Valverde

Departamento de Teoría e Historia Económica

Facultad de CCEE y Empresariales

Universidad de Granada

s/n E-18071, Granada, Spain

scarbo@ugr.es

Edward J. Kane

Department of Finance

Boston College

Chestnut Hill, MA 02467

and NBER

edward.kane@bc.edu
Francisco Rodriguez-Fernandez

Departamento de Teoría e Historia Económica

Facultad de CCEE y Empresariales

Universidad de Granada

s/n E-18071, Granada, Spain

franrod@ugr.es 
February 1, 2011

\section{SAFETY-NET BENEFITS CONFERRED ON DIFFICULT-TO-FAIL-AND-UNWIND BANKS IN THE US AND EU BEFORE AND DURING THE GREAT RECESSION \\ Santiago Carbo-Valverde \\ Edward J. Kane \\ Francisco Rodriguez-Fernandez}

A nation's financial safety net is a set of programs aimed at protecting bank depositors and keeping systemically important markets and institutions from breaking down in difficult circumstances. Although different instruments and functions are often located in different agencies, the organization can be seen as a government-owned holding company. Considered as a consolidated enterprise, this collection of agencies has a balance sheet, an income statement, and a governance network across which stakeholders and managers interact. Its governance procedures are complicated by differences in the capacities of different stakeholders to understand and promote their interests and these differences vary widely across countries.

The current financial crisis has hit some countries much harder than others. This paper seeks to benchmark differences in how well, both before and during the current crisis, safety-net managers in the US and 14 European countries managed the tradeoff in their systems of institutional support between the interests of bankers and taxpayers.

The principal goal of safety-net management is to monitor, contain, and finance systemic risk. Systemic risk combines two kinds of risk-taking: calculated risk-taking by protected institutions and partially countervailing risk-management programs operated by safety-net managers. Ideally, safety-net managers safeguard taxpayers interests by making institutions operate more safely than stockholders might prefer.

Definitions of systemic risk used by the Basel Committee and other policymakers focus on a perceived potential for substantial spillovers of institutional defaults across important firms in the financial sector and from this sector to employment and asset values in the real economy. But this 
perspective conceives of safety-net managers as managing a negative externality rather than completing markets by tolerating and redistributing downside risk to taxpayers. Because research indicates that stock markets do price downside risk at protected institutions, taxpayer exposure to this risk is not strictly an externality. The conjectural contingent obligations that government safety nets impose on taxpayers guarantee the performance of particular contracts in adverse circumstances. In effect, they complete what would otherwise be a system of incomplete markets for the liabilities of protected firms (cf., Kane, 1980). Since costs to taxpayers of underwriting tail risks at these institutions are not expected to be recovered in full by means of ex post assessments, national safety nets are programs of redistributive fiscal policy that encourage excessive risk taking by systemically important firms.

One lesson of the current crisis is that the aggregate costs and benefits of producing government guarantees are not much different from their private costs and benefits. Despite the global extent of the current crisis, actual spillovers of defaults have been minimal. Firms that seemed politically or administratively difficult to fail and unwind (DFU firms) have been characterized as systematically important and kept running by supporting their access to public and private credit without resolving their underlying shortage of capital (i.e. their economic insolvency). In effect, authorities exercised a loss-shifting "taxpayer put" that converted most of the losses incurred by insolvent DFU firms into government debt (Kane, 1986; Eberlein and Madan, 2010).

The capitalized value of the safety-net subsidies that DFU firms capture from taxpayers represents a cogent way to measure what authorities ought to mean by "systemic risk." This definition of systemic risk implies that, even in good times, ex ante safety-net subsidies exist for DFU firms. Of course, ex post subsidies become more plainly visible as prominent firms' booked and unbooked losses approach a breaking point. Ironically, in economic downturns, this increased transparency can fuel popular unrest that reduces the flow of ex ante subsidies to banks that do not receive explicit open-bank assistance. On average, but not at the margin, we observe such an effect across our sample and 
subsamples. These distribution effects suggest that taxpayer and competitor interests would be better

served-- in good times and in bad--by surfacing estimates of the buildup of safety-net subsidies and recording these estimates on the income statements and balance sheets of governments and DFU firms alike.

Both in Europe and the US, safety-net managers seek to contain risk-taking by restricting the activities of protected institutions and by prescribing risk-based capital requirements and insurance premia. The empirical part of this paper uses the Bankscope database and contingent-claims models of safety-net benefits to estimate and compare the value of leverage ratios and ex ante safety-net benefits at firms thought or revealed to be DFU in the US and Europe during 2003-2008. We find that during both 2003-2006 and 2007-2008 DFU banks in both venues enjoyed substantially higher ex ante benefits than other institutions in the sample. Safety-net benefits were significantly larger for DFU firms in Europe, but bailout decisions appear less driven by asset size and more by regulatory capture than in the United States.

\section{Modeling the Determinants of Systemic Risk}

Considerable disagreement exists about the best way to measure systemic risk, but everyone agrees that it arises as a mixture of leverage and the volatility of financial-institution returns. This paper employs a two-equation model developed by Duan, Moreau, and Sealey (DMS, 1992). In this model, decisions about volatility constrain leverage decisions and, abetted by leverage, generate safety-net benefits. The model incorporates the pioneering perspective of Merton $(1977,1978)$. Adding ideas from Ronn and Verma (1986) and Hovakimian and Kane (2000), two other studies [Carbo, Kane, and Rodriguez $(2008,2010)]$ use this model to undertake cross-country comparisons of regulatory and merger policies. 
The DMS model recognizes that market and regulatory discipline force a financial firm to carry an equity position that outsiders regard as large enough to support the risks it takes. However, creditors are assumed to regard the conjectural value of the off-balance-sheet capital that government guarantees supply through the taxpayer put as a substitute for on-balance-sheet capital supplied by the firm's shareholders.

For individual banks, the DMS model consists of a leverage equation and an equation tracking safety-net benefits. This model linearizes and slightly expands Merton's model of deposit insurance $(1977,1978)$. Merton portrays safety-net access as an option that allows bank owners to put the bank to safety-net managers in exchange for the face value of the bank's debt. Ronn and Verma (1986) suggest scaling down this option's exercise right to allow for examination lags and political pressures that make it hard for authorities to enforce their takeover rights.

Firms engage in risk-shifting whenever they expose creditors, derivatives counterparties or guarantors to loss without compensating them adequately. The DMS model measures safety-net benefits by a variable designated as IPP. IPP is the so-called "fair insurance premium percentage" per dollar, per Euro, or per pound of debt that would let taxpayers break even in each period. The model makes IPP an increasing function of a bank's asset risk $\left(\sigma_{\mathrm{V}}\right)$ and leverage. Leverage is measured as the ratio of the par value of an institution's debt (B) to the estimated market value of its assets (V).

Duan, Moreau, and Sealey (1992) stress that market and regulatory disciplines prevent valuemaximizing $\mathrm{B} / \mathrm{V}$ (leverage) from being chosen independently of $\sigma_{\mathrm{V}}$ (volatility). To contain risk-shifting at all, counterparties and regulators must require $B / V$ to fall when and as $\sigma_{\mathrm{v}}$ increases. The model is only a quasi-reduced form because it treats a potentially exogenous variable $\sigma_{\mathrm{V}}$ as an exogenous regressor. This produces a recursive model for bank B/V and IPP:

$$
\begin{aligned}
& B / V=\alpha_{0}+\alpha_{1} \sigma_{V}+\varepsilon_{1} . \\
& I P P=\beta_{0}+\beta_{1} \sigma_{V}+\varepsilon_{2} .
\end{aligned}
$$


Equation (1) expresses the idea that regulators and creditors constrain bank risk-taking to a mutually acceptable set of leverage and volatility pairs. If safety-net managers had no incentive conflicts and could observe $\sigma_{v}$ and control B/V perfectly, they would set B/V so that IPP equaled the value of the sum of explicit and implicit premiums they could impose on the bank. Taking total derivatives, the slope coefficients in (1) and (2) may be interpreted as follows:

$$
\begin{aligned}
& \sigma_{1}=\frac{d\left(B / V_{2}\right)}{d \sigma_{N}} \\
& \beta_{1}=\frac{\partial I F R}{\partial \sigma V}+\frac{\partial I R F}{\partial(E / V)} \alpha_{1}=\gamma_{1}+\gamma_{2} \alpha_{1} .
\end{aligned}
$$

The partial derivatives that appear in equation (4) are positive. They describe the incremental value that bank stockholders could extract from the safety net if bankers were free to make unconstrained adjustments in volatility and leverage, respectively. To prevent a corner solution, either or both of two conditions must be met. Safety-net officials and private counterparties must monitor and constrain bank risk taking at the margin or managers must believe that unbridled pursuit of safetynet subsidies would work against their career interests. Equations (3) and (4) express the effects of "outside discipline." At DFU banks during the years we examine, managerial restraint or "inside discipline" seems to have been sorely lacking.

Given the external discipline a bank faces, the sign of $\beta_{1}$ in equation (2) indicates whether, in a country's particular contracting environment and economic circumstances, increases in asset volatility can increase the value of the implicit and explicit access to safety-net support that is imbedded in the bank's stock price. To neutralize risk-shifting incentives at the margin, disciplinary penalties that induce a decline in B/V must be large enough to offset fully whatever increase in IPP might otherwise be generated by choosing a higher $\sigma_{\mathrm{v}}$. In firms for which the total derivative $\beta_{1}$ is positive, marginal riskshifting incentives are not completely neutralized by inside and outside discipline.

For market and regulatory pressure to discipline and potentially to neutralize incremental risk-shifting incentives, two conditions must be met: 
Bank capital increases with volatility: $\quad \alpha_{1}<0$,

Guarantee values do not rise with volatility: $\quad \beta_{1} \leq 0$.

None of the three variables featured in the DMS model is directly observable. However, Marcus and Shaked (1984) show how to use option-based models of deposit insurance to track these variables synthetically. The first step in the Marcus-Shaked procedure is to obtain tracking values for $\mathrm{V}$ and $\sigma_{V}$ by numerical methods. These values are then used to estimate IPP as the value of a put option on bank assets (the "default put"). As explained more fully in Hovakimian and Kane (2000), a key step is to use Ito's lemma to transform $\sigma_{V}$ into $\sigma_{E}$, the instantaneous standard deviation of equity returns.

\section{Preliminary Look at Mean Sample Experience}

Table 1 lists the number of observations in our sample by country. Over a third of the observations come from the US and Germany and roughly 80 percent come from the last six countries listed in the table. Table 2 lists the sources from which we obtain the data we analyze. It also introduces and defines some control and shift variables (such as DFU status) that we incorporate into our regression experiments. DFU status is proxied ex ante by a size criterion (DFUxa) and ex post by the receipt of open-bank assistance (DFUxp).

Table 3 describes the mean behavior of leverage, volatility, and the fair insurance premium percentage for different groupings of banks. Throughout the paper, regression inputs are calculated in two different ways: by the Ronn and Verma (RV) procedure and by a maximum-likelihood (ML) method developed by Duan (1994). Table 3 also records the results of tests for differences in the mean values found between US and European banks and between DFU and other banks in various regions. Mean differences are significant at conventional levels in every instance.

Mean safety-net benefits range between 10 and 22 basis points. Mean leverage proves uniformly higher under the ML procedure, while volatility and IPP are often lower. Using either procedure, both kinds of DFU banks show higher safety-net benefits than other banks in both regions 
and time frames. In most cases, DFU institutions show more leverage, too. Both before and during the crisis, DFU banks in Europe show more leverage and safety-net benefits than DFU banks in the US and DFUxp banks extracted more benefits than DFUxa firms. During the crisis, DFU banks in Europe and the US decreased volatility, reduced their leverage and did suffer procyclical cuts in the mean size of ex ante safety net benefits.

\section{Regression Analysis}

Difference-on-difference regression experiments expand equations (1) and (2) to include three control variables and three parameter-shift indicators for DFU banks ${ }^{1}$. The log of asset size is introduced as a hard-to-interpret proxy that aggregates the influence of political clout, complexity, and public awareness separately from measures of DFU status per se. Transparency International's Corruption Perception Index (10-CPI) is used to represent cross-country differences in a government's susceptibility to regulatory capture. We include the so-called "fear index" (VIX) as a way to distinguish the impacts of marketwide and idiosyncratic volatility.

Pooling precrisis and crisis years, Table 4 applies this model separately to panels of US and European banks and bank holding companies. The signs of all coefficients and the rough magnitude of $p$ values are similar in all parallel runs.

Given the large size of these samples and the near-zero value of focal coefficients, the Lindley Paradox suggests that we employ a more rigorous standard for statistical significance than the conventional 5 percent. Our discussions benchmark significance at 2 percent, but the reader is free to adopt a lighter or tougher standard.

The shift variable in the size effect for DFU banks is never significant and is dropped from subsequent runs. Except for VIX and the corruption index (which proves significant only in Europe where there is cross-section as well as time-series variation), most differences between US and European

\footnotetext{
${ }^{1}$ See Han and Phillips (2011) for a comprehensive discussion of fixed-effects panel estimation in difference-ondifference regression.
} 
leverage equations meet the significance standard of 2 percent. The effects of asset size on safety-net benefits (i.e., on IPP) are similar across countries, but at the margin DFUxa banks in the US extract slightly more benefits than their European counterparts.

Table 5A shows the effect of employing the ex post definition of the DFU shift variable. In this experiment, DFUxp banks are banks that received explicit State aid during the crisis. Although R-squared remains much the same, this definition renders differences between Europe and the US in coefficients for idiosyncratic volatility, asset size, corruption, and the intensified role of volatility for DFU banks sharper and uniformly more significant. In particular, even though DFUxp banks in the US find themselves penalized more heavily for increased volatility in the leverage equation than DFUxp banks in the EU, they manage to extract incremental benefits from the safety net more successfully 0.035 in the US vs. 0.029 in Europe according to the ML procedure). Additionally, the proxy for regulatory capture (10-CPI) is significant only for the EU sample.

Table 5B re-runs the Table 5A regression experiment using Heckman's $(1976,1978)$ procedure for endogenizing the ex post selection process for providing capital support to DFU banks. This procedure adds a third equation to our model. This selection equation is linked to the other equations by a variable that Heckman calls Lambda (also known as the Mills Odds Ratio for selection) which is calculated from the selection model. This linking variable is then added to the list of the potential determinants of leverage and safety-net benefits in expanded versions of equations (1) and (2).

Although the value and significance of coefficients in the B/V and IPP models are not much different from those in Table 5A, differences in the probit selection models for receiving State aid are markedly different. In Europe, asset size has no significant effect. Idiosyncratic volatility and the corruption index dominate government bailout decisions in Europe. In particular, the impact of $\sigma_{\mathrm{V}}$ on the probability of receiving State aid in Europe is 0.815 according to the ML model while the impact of the regulatory capture proxy (CPI-10) is 0.916 . In the US, idiosyncratic volatility is more or less equally 
important, but size has a large effect. The coefficient for size at US banks estimated with either the RV and ML procedure is roughly 1.50. Limited to time-series variation, the corruption index shows no predictive power in the US.

Tables $6 \mathrm{~A}$ and $6 \mathrm{~B}$ run the abridged model of Table 4 separately for pre-crisis and crisis years: i.e., for 2003-2006 and 2007-2008. The most interesting differences are those in which the subperiod coefficients both lie substantially above or below those found in the pooled equation. Such a finding establishes a prima facie case against pooling data across separate regimes. This phenomenon occurs for the incremental effects on IPP of the DFUxa shift variable in both regions $(+)$, for corruption $(+)$ in Europe, and for size (-) and volatility (+) in the US. In particular, taking the ML model as a reference, the coefficient of the critical DFU shift variable in the IPP equation changes only slightly (from 0.026 to 0.029) in the EU sample from the pre-crisis to the crisis period. But the coefficient for the US sample shows increased marginal subsidization, jumping from 0.034 to 0.044 . As for the index of corruption perceptions, the coefficient in the IPP equation almost doubles (from 0.007 to 0.012 ), while the index continues to be insignificant in the US sample. The coefficient of $\sigma_{v}$ in the IPP equation increases for the EU sample from 0.007 in precrisis years to 0.011 in the crisis period while the coefficient for the US sample increases hardly at all, from 0.013 to 0.015 .

Table 7 reports the significance of differences between coefficients in precrisis and crisis years for US and European banks separately. In Europe, crisis years show an intensification in incremental subsidization for a few variables and equations: for idiosyncratic volatility on safety-net benefits; for the DFU shift variable on leverage under the ML procedure and on IPP using the RV approach; and for corruption in the leverage equation and in the ML model for IPP. In the US, the incremental effects of asset size and the DFU shift variable intensify for both variables under both procedures.

Tables $8 \mathrm{~A}$ and $8 \mathrm{~B}$ re-run the experiments of Tables $6 \mathrm{~A}$ and $6 \mathrm{~B}$ using the Heckman procedure and the ex post DFU indicator. For both the precrisis and crisis eras, the signs of all coefficients for the 
European and US samples remain the same. However, the magnitude of individual coefficients is often reduced. For the precrisis samples, coefficient differences between US and Europe for the corruption and VIX index are seldom significant, but the greater role for market volatility in explaining US bank leverage in crisis years continues to be significant.

As in Table 5, the importance of the Heckman experiments lies in creating the opportunity to examine the selection equations. Asset size (and to a lesser extent, idiosyncratic volatility) is a more important determinant of bailout assistance in the US than in Europe, while a European country 's corruption index strongly influences its bailout decisions. The inference is that banks may not be too big to fail in Europe, but they might be too politically connected.

For European and US sample banks, Table 9 shows that the leverage and IPP equations underwent many statistically significant changes between precrisis and crisis periods. Economically, the effects on IPP generation are the most interesting. In Europe, the shift in the volatility slope for DFU banks explicitly receiving State aid increased by roughly 50 percent under both procedures. In the US, this coefficient also increased, but the effect is smaller and significant only under the RV procedure.

\section{Special Cases of Portugal, Ireland, Italy, and Spain}

In some European countries affected most severely by the crisis, doubt has arisen about the government's ability to resolve the losses experienced by its largest banks. Greece (for which we lack data), Ireland, Portugal, Italy, and Spain have all seen substantial increases in the credit premium paid on their sovereign debt. Tables $10 \mathrm{~A}$ and $10 \mathrm{C}$ apply the expanded DMS model to the high-premium countries for which we have data.

Although idiosyncratic volatility is always significant in these four countries, market volatility is not. Time-series variation in the index of perceived corruption almost always impacts leverage, IPP, and selection significantly. However, the economic significance of the proxy for susceptibility to regulatory capture (10-CPI) is higher in Ireland (0.021 in the ML version of the IPP equation) than in Portugal 
February 1, 2011

(0.011), Spain (0.008) or Italy (0.006). Size impacts selection except in Portugal. Idiosyncratic volatility increases safety-net benefits more in Portugal (0.010) and Ireland (0.018) than in Spain (0.008) and Italy (0.006).

Table $10 \mathrm{C}$ shows that almost all coefficient differences are significant across country pairs. Ignoring coefficient differences and discarding the market-volatility term, Table 11 tests for differences that apply in precrisis and crisis periods when the DMS model fitted to the DFU banks that were bailed out in these four countries is compared with the Table $6 \mathrm{~A}$ and $6 \mathrm{~B}$ models estimated across the full sample of European banks. The most striking differences between these two panels and periods is the much greater importance found during the crisis years for asset size and the proxy for susceptibility to regulatory capture.

\section{Lessons and Policy Implications}

Three important lessons emerge from our work. The first concerns authorities' convenient claim that crisis pressures could not be foreseen. Despite being limited to annual data for key variables, changes in volatility and leverage consistently help to predict changes in the flow of safety-net benefits across different models, regions, and time periods. The second lesson is that the mean flow of ex ante benefits declined in the face of the increased public accountability generated by the transparency of $\underline{\text { ex }}$ post bailout expense. Finally, the cross-country proxy for susceptibility to regulatory capture (the index of perceived corruption) helps to explain safety-net benefits and bailout decisions in Europe.

One policy implication of these findings is that authorities could do a better job of controlling safety-net benefits if they expanded their information systems so that they could track IPP in a transparent manner. As intricate as it may seem, the stochastic and econometric plumbing underlying our equities-based estimates of volatility and safety-net benefits is still at an early stage of evolution. Complementary estimates can be engineered using richer stochastic processes and datasets based on 
the prices of debt and derivative instruments. We encourage others to do this and are confident that they will.

One way to improve information flow would be to require that bank managers report data on earnings and net worth more frequently, with civil penalties for fraud and negligent misrepresentation. Data on market capitalization are available in real time, as are data on stock-market returns. If the values of on-balance-sheet and off-balance-sheet positions were reported weekly or monthly to national authorities, rolling regression models could be used to estimate changes in the flow of safety-net benefits in ways that would allow regulators to observe, manage and report taxpayers' stake in the safety net in a more timely manner. 


\section{REFERENCES}

Carbo, Santiago, Edward Kane, and Francisco Rodriguez. (2008) "Evidence of Differences in the Effectiveness of Safety-Net Management in European Union Countries," Journal of Financial Services Research, 34, 151-76.

(2010). "Regulatory Arbitrage in Cross-Border Mergers Within the EU," Journal of Money Credit and Banking (forthcoming).

Duan, Jin-Chuan. (1994). "Maximum Likelihood Estimation Using Price Data of the Derivative Contract," Mathematical Finance, 4, 155-67.

Duan, J-C, Arthur F. Moreau, and C. William Sealey. (1992) "Fixed-Rate Deposit Insurance and RiskShifting Behavior at Commercial Banks," Journal of Banking and Finance, 16, 715-42.

Duan, Jin-Chuan, and Jean-Guy Simonato. (2002) "Maximum Likelihood Estimation of Deposit Insurance Value with Interest-Rate Risk," Journal of Empirical Finance, 9, 109-32.

Eberlein, E. and D.B. Madan. (2010) Capital requirements, and taxpayer put option values for the major US banks. Mimeo.

Han, Chirok and Peter C.B. Phillips (2011) "First difference MLE and dynamic panel estimation", Cowles Foundation Discussion Paper No. 1780.

Heckman, James. (1976) "The Common Structure of Statistical Models of Truncation, Sample Selection and Limited Dependent Variables and a Sample Estimator for Such Models," Annals of Economic and Social Measurement, 5, 475-92.

. (1978) "Dummy Endogenous Variables in a Simultaneous Equation System,"

Econometrica, 46, 931-59.

Hovakimian, Armen, and Edward J. Kane. (2000) "Effectiveness of Capital Regulation at U.S. Commercial Banks, 1985-1994," Journal of Finance, 55(March), 451-469.

Kane, Edward J., 1980. "Market Incompleteness and Divergences Between Forward and Future Interest Rates," Journal of Finance, 35, 221-234.

. (1986). Appearance and reality for deposit institutions: The case for reform, Journal of Banking and Finance, 175-188.

. (2009) "Extracting Nontransparent Safety Net Subsidies by Strategically Expanding and Contracting a Financial Institution's Accounting Balance Sheet," Journal of Financial Services Research, 36, 161-68.

Marcus, Alan, and Israel Shaked. (1984) "The Valuation of FDIC Deposit Insurance Using Option-Pricing Estimates," Journal of Money, Credit, and Banking, 16, 446-460. 
Merton, Robert C. (1977) "An Analytic Derivation of the Cost of Deposit Insurance and Loan Guarantees," Journal of Banking and Finance, 1, 3-11.

. (1978). "on the Cost of Deposit Insurance When There Are Surveillance Costs," Journal of Business, 51, 439-52.

Molyneux, Philip, Klaus Schaeck, and Tim Mi Zhou. (2010) 'Too-Big-to-Fail' and Its Impact on Safety Net Subsidies and Systemic Risk, Bangor, Wales: Bangor University Working Paper.

Ronn, Ehud, and A.R. Verma. (1986) "Pricing Risk-Adjusted Deposit Insurance: An Option-Based Model," Journal of Finance, 41, 871-95. 
February 1, 2011

\section{TABLE 1}

SAMPLE SIZE (NUMBER OF OBSERVATIONS)

Frequency: annual (2003-2008)

\begin{tabular}{|c|c|} 
Austria & 476 \\
\hline Belgium & 627 \\
\hline Denmark & 206 \\
\hline Finland & 78 \\
\hline Luxembourg & 426 \\
\hline Netherlands & 203 \\
\hline Portugal & 158 \\
\hline Sweden & 263 \\
\hline Ireland & 157 \\
\hline United & \\
Kingdom & 864 \\
\hline Spain & 531 \\
\hline France & 1112 \\
\hline Italy & 1236 \\
\hline Germany & 2227 \\
\hline United States & 2153 \\
\hline TOTAL & $\mathbf{1 1 1 1 7}$ \\
\hline
\end{tabular}


February 1, 2011

TABLE 2

DEFINITIONS AND SOURCES FOR VARIABLES

\begin{tabular}{|c|c|c|}
\hline Variable & Definition & Source \\
\hline $\mathrm{B} / \mathrm{V}(\%)$ & $\begin{array}{l}\text { Leverage, measured as the ratio of the book value }(B) \text { of } \\
\text { deposits and other debt to the market value of a bank's assets } \\
(V) \text {. }\end{array}$ & $\begin{array}{l}\text { Bank-level data to compute } \\
\text { this variable are obtained } \\
\text { from the Bureau-Van Dijk } \\
\text { Bankscope database. }\end{array}$ \\
\hline IPP (\%) & $\begin{array}{l}\text { "Fair" insurance premium percentage, defined as the per-period } \\
\text { flow of safety-net benefits that bank stockholders enjoy. }\end{array}$ & $\begin{array}{l}\text { Bank-level data to compute } \\
\text { this variable are obtained } \\
\text { from the Bureau-Van Dijk } \\
\text { Bankscope database. }\end{array}$ \\
\hline$\sigma_{\vee}(\%)$ & $\begin{array}{c}\text { Volatility, defined as the standard deviation of the return on } \\
\text { bank assets }\end{array}$ & $\begin{array}{l}\text { Bank-level data to compute } \\
\text { this variable are obtained } \\
\text { from the Bureau-Van Dijk } \\
\text { Bankscope database. } \\
\end{array}$ \\
\hline $\begin{array}{l}\text { Size (log total } \\
\text { assets) (Eur mill) }\end{array}$ & Size of the banks measured by total book value of assets. & $\begin{array}{l}\text { Bank-level data to compute } \\
\text { this variable are obtained } \\
\text { from the Bureau-Van Dijk } \\
\text { Bankscope database. }\end{array}$ \\
\hline $\begin{array}{l}\text { Corruption } \\
\text { perception index } \\
(10-C P I)\end{array}$ & $\begin{array}{l}\text { Transparency International's Corruptions Perceptions Index } \\
\text { (CPI) is an aggregate indicator that ranks countries in terms of } \\
\text { the degree to which corruption is perceived to exist among } \\
\text { public officials and politicians. It is a composite index drawing } \\
\text { on corruption-related data by a variety of independent and } \\
\text { reputable institutions. The main reason for using an aggregated } \\
\text { index of individual sources is that a combination of sources } \\
\text { measuring the same phenomenon is more reliable than each } \\
\text { source taken separately. The CPI ranges } 1 \text { to } 10 \text {. Higher values } \\
\text { of the index show less corruption. In order to normalize the } \\
\text { values we have redefined the indicator as } 10-\mathrm{CPI} \text { so that higher } \\
\text { values show more corruption. }\end{array}$ & $\begin{array}{l}\text { Transparency international } \\
\text { (www.transparency.org) }\end{array}$ \\
\hline $\begin{array}{l}\text { Market volatility } \\
\text { (VIX) }\end{array}$ & $\begin{array}{l}\text { The VIX is calculated and disseminated in real-time by the } \\
\text { Chicago Board Options Exchange. It is a weighted blend of } \\
\text { prices for a range of options on the S\&P } 500 \text { index. On March } \\
26,2004 \text {, the first-ever trading in futures on the VIX Index } \\
\text { began on CBOE Futures Exchange (CFE). The formula uses a } \\
\text { kernel-smoothed estimator that takes as inputs the current } \\
\text { market prices for all out-of-the-money calls and puts for the } \\
\text { front month and second month expirations.[1] The goal is to } \\
\text { estimate the implied volatility of the S\&P } 500 \text { index over the } \\
\text { next } 30 \text { days. The VIX is the square root of the par variance } \\
\text { swap rate for a } 30 \text { day term initiated today. Note that the VIX is } \\
\text { the volatility of a variance swap and not that of a volatility swap } \\
\text { (volatility being the square root of variance). }\end{array}$ & $\begin{array}{l}\text { Chicago Board of Exchange } \\
\text { (http://www.cboe.com/ } \\
\text { micro/vix/introduction.aspx) }\end{array}$ \\
\hline DFU Status & $\begin{array}{l}\text { A binary variable that takes on the value of unity for banks that } \\
\text { alternately either received open-bank assistance (DFUxp) or fell } \\
\text { in the first decile of average } 2003-2008 \text { asset size for US and } \\
\text { European banks in the Bankscope database (DFUxa). }\end{array}$ & $\begin{array}{l}\text { Deciles are calculated by } \\
\text { the authors. } \\
\text { Identity of banks receiving } \\
\text { equity injections is hand- } \\
\text { collected. }\end{array}$ \\
\hline
\end{tabular}


February 1, 2011

\section{TABLE 3}

MEAN LEVERAGE RATIO (B/V), MEAN FAIR PREMIUM (IPP), AND VOLATILITY OF RETURN ON ASSETS $\left(\sigma_{\mathrm{v}}\right)$ : ALL BANKS, DFUxa and DFUxp BANKS IN EUROPE AND IN THE US

\begin{tabular}{|c|c|c|c|c|c|c|}
\hline \multirow[t]{2}{*}{ Country } & \multicolumn{2}{|c|}{$\mathrm{B} / \mathrm{V}(\%)$} & \multicolumn{2}{|c|}{ IPP (\%) } & \multicolumn{2}{|c|}{$\sigma_{\mathrm{V}}(\%)$} \\
\hline & RV & $\mathrm{ML}$ & $\mathrm{RV}$ & $\mathrm{ML}$ & RV & ML \\
\hline ALL BANKS (FULL SAMPLE) & 84.8 & 87.1 & 0.143 & 0.119 & 1.815 & 1.582 \\
\hline ALL BANKS IN EUROPE & 85.3 & 86.0 & 0.153 & 0.134 & 1.988 & 1.727 \\
\hline ALL BANKS IN THE US & 82.5 & 83.9 & 0.139 & 0.127 & 1.490 & 1.368 \\
\hline DFUxa BANKS (FULL SAMPLE) & 86.9 & 89.8 & 0.167 & 0.145 & 1.593 & 1.597 \\
\hline DFUxp BANKS (FULL SAMPLE) & 88.0 & 90.9 & 0.174 & 0.156 & 1.669 & 1.490 \\
\hline DFUxa BANKS IN EUROPE & 88.1 & 90.0 & 0.179 & 0.164 & 1.696 & 1.487 \\
\hline DFUxp BANKS IN EUROPE & 89.3 & 91.6 & 0.189 & 0.180 & 1.792 & 1.594 \\
\hline DFUxa BANKS IN THE US & 80.5 & 82.2 & 0.127 & 0.116 & 1.396 & 1.284 \\
\hline DFUXP BANKS IN THE US & 83.4 & 84.2 & 0.140 & 0.134 & 1.503 & 1.411 \\
\hline ALL BANKS IN EUROPE (PRE 2007) & 86.7 & 88.0 & 0.157 & 0.163 & 2.134 & 2.166 \\
\hline ALL BANKS IN THE US (PRE 2007) & 83.2 & 83.9 & 0.149 & 0.156 & 1.529 & 1.632 \\
\hline ALL BANKS IN EUROPE (2007-2008) & 83.9 & 84.3 & 0.132 & 0.138 & 1.842 & 1.931 \\
\hline ALL BANKS IN THE US (2007-2008) & 81.1 & 81.5 & 0.128 & 0.137 & 1.344 & 1.388 \\
\hline DFUxa BANKS IN EUROPE (PRE 2007) & 90.4 & 92.6 & 0.198 & 0.185 & 1.591 & 1.403 \\
\hline DFUxa BANKS IN THE US (PRE 2007) & 81.5 & 82.4 & 0.158 & 0.146 & 1.343 & 1.211 \\
\hline DFUxa BANKS IN EUROPE (2007-2008) & 85.7 & 88.6 & 0.165 & 0.150 & 1.967 & 1.663 \\
\hline DFUxa BANKS IN THE US (2007-2008) & 78.2 & 80.1 & 0.119 & 0.102 & 1.491 & 1.396 \\
\hline DFUxp BANKS IN EUROPE (PRE 2007) & 92.3 & 93.4 & 0.215 & 0.220 & 1.635 & 1.523 \\
\hline DFUxp BANKS IN THE US (PRE 2007) & 83.8 & 84.1 & 0.176 & 0.160 & 1.428 & 1.323 \\
\hline DFUxp BANKS IN EUROPE (2007-2008) & 89.9 & 90.1 & 0.179 & 0.162 & 2.123 & 1.815 \\
\hline DFUxp BANKS IN THE US (2007-2008) & 82.3 & 83.1 & 0.129 & 0.118 & 1.538 & 1.493 \\
\hline Mean difference tests: ALL BANKS IN EUROPE vS. ALL BANKS IN THE US & 0.006 & 0.007 & 0.008 & 0.005 & 0.009 & 0.007 \\
\hline Mean difference tests: ALL BANKS vs. DFUxa BANKS (FULL SAMPLE) & 0.012 & 0.011 & 0.008 & 0.004 & 0.005 & 0.006 \\
\hline Mean difference tests: ALL BANKS vs. DFUxp BANKS (FULL SAMPLE) & 0.008 & 0.006 & 0.005 & 0.003 & 0.002 & 0.001 \\
\hline Mean difference tests: DFUxa vs. DFUxp BANKS (FULL SAMPLE) & 0.005 & 0.004 & 0.003 & 0.001 & 0.001 & 0.001 \\
\hline $\begin{array}{c}\text { Mean difference tests: } A L L \text { BANKS IN EUROPE vs. DFUxa BANKS IN } \\
\text { EUROPE }\end{array}$ & 0.009 & 0.007 & 0.004 & 0.003 & 0.004 & 0.002 \\
\hline Mean difference tests: ALL BANKS IN THE US vS. DFUxa BANKS IN THE US & 0.012 & 0.013 & 0.013 & 0.015 & 0.019 & 0.016 \\
\hline $\begin{array}{c}\text { Mean difference tests: ALL BANKS IN EUROPE vs. DFUxp BANKS IN } \\
\text { EUROPE }\end{array}$ & 0.007 & 0.005 & 0.0003 & 0.001 & 0.002 & 0.002 \\
\hline Mean difference tests: ALL BANKS IN THE US vS. DFUxa BANKS IN THE US & 0.009 & 0.010 & 0.010 & 0.011 & 0.013 & 0.010 \\
\hline $\begin{array}{c}\text { Mean difference tests: DFUxa BANKS IN EUROPE vs. DFUxp BANKS IN THE } \\
\text { US }\end{array}$ & 0.002 & 0.003 & 0.005 & 0.004 & 0.007 & 0.006 \\
\hline $\begin{array}{c}\text { Mean difference tests: DFUxp BANKS IN EUROPE vs. DFUxp BANKS IN THE } \\
\text { US }\end{array}$ & 0.001 & 0.001 & 0.003 & 0.002 & 0.004 & 0.004 \\
\hline $\begin{array}{c}\text { Mean difference tests: ALL BANKS IN EUROPE (PRE 2007) vS. DFUxa BANKS } \\
\text { IN EUROPE (PRE 2007) }\end{array}$ & 0.005 & 0.003 & 0.004 & 0.002 & 0.004 & 0.003 \\
\hline $\begin{array}{c}\text { Mean difference tests: ALL BANKS IN THE US (PRE 2007) vS. DFUxa BANKS } \\
\text { IN THE US (PRE 2007) }\end{array}$ & 0.012 & 0.014 & 0.005 & 0.004 & 0.006 & 0.004 \\
\hline $\begin{array}{c}\text { Mean difference tests: ALL BANKS IN EUROPE (2007-2008) vs. DFUxa } \\
\text { BANKS IN EUROPE (2007-2008) }\end{array}$ & 0.004 & 0.003 & 0.005 & 0.003 & 0.002 & 0.004 \\
\hline $\begin{array}{c}\text { Mean difference tests: ALL BANKS IN THE US (2007-2008) vS. DFUxa BANKS } \\
\text { IN THE US (2007-2008) }\end{array}$ & 0.008 & 0.011 & 0.005 & 0.007 & 0.004 & 0.005 \\
\hline $\begin{array}{c}\text { Mean difference tests: DFUxa IN EUROPE (PRE 2007) VS. DFUxa IN } \\
\text { EUROPE (2007-2008) }\end{array}$ & 0.010 & 0.009 & 0.012 & 0.015 & 0.011 & 0.017 \\
\hline $\begin{array}{c}\text { Mean difference tests: DFU IN THE US (PRE 2007) VS. DFUxa IN THE US } \\
(2007-2008)\end{array}$ & 0.008 & 0.007 & 0.010 & 0.005 & 0.013 & 0.010 \\
\hline $\begin{array}{c}\text { Mean difference tests: ALL BANKS IN EUROPE (PRE 2007) vS. DFUxp BANKS } \\
\text { IN EUROPE (PRE 2007) }\end{array}$ & 0.001 & 0.001 & 0.001 & 0.001 & 0.002 & 0.002 \\
\hline $\begin{array}{l}\text { Mean difference tests: ALL BANKS IN THE US (PRE 2007) vs. DFUxp BANKS } \\
\text { IN THE US (PRE 2007) }\end{array}$ & 0.008 & 0.009 & 0.003 & 0.002 & 0.004 & 0.003 \\
\hline $\begin{array}{c}\text { Mean difference tests: ALL BANKS IN EUROPE (2007-2008) vs. DFUxp } \\
\text { BANKS IN EUROPE (2007-2008) }\end{array}$ & 0.002 & 0.002 & 0.003 & 0.001 & 0.001 & 0.002 \\
\hline $\begin{array}{l}\text { Mean difference tests: ALL BANKS IN THE US (2007-2008) vS. DFUxp BANKS } \\
\text { IN THE US (2007-2008) }\end{array}$ & 0.002 & 0.001 & 0.002 & 0.004 & 0.002 & 0.003 \\
\hline $\begin{array}{c}\text { Mean difference tests: DFUxp IN EUROPE (PRE 2007) VS. DFUxp IN } \\
\text { EUROPE (2007-2008) }\end{array}$ & 0.008 & 0.006 & 0.010 & 0.011 & 0.008 & 0.013 \\
\hline $\begin{array}{c}\text { Mean difference tests: DFU IN THE US (PRE 2007) VS. DFUxp IN THE US } \\
(2007-2008)\end{array}$ & 0.006 & 0.004 & 0.006 & 0.004 & 0.010 & 0.007 \\
\hline
\end{tabular}


TABLE 4

SINGLE-EQUATION ESTIMATES OF THE EFFECTIVENESS OF SAFETY-NET CONTROL: ALL BANKS AND DFUxa BANKS IN EUROPE AND IN THE US

Fixed-effects panel regressions relating changes in a bank's leverage, $\Delta B / V$, and changes in its fair insurance premium percentage, $\triangle I P P$, to the changes in volatility of its assets, $\Delta \sigma_{\mathrm{V}} . B$ is the face value of bank's debt, including deposits. $V$ is the market value of bank assets. The errors are clustered at the firm level

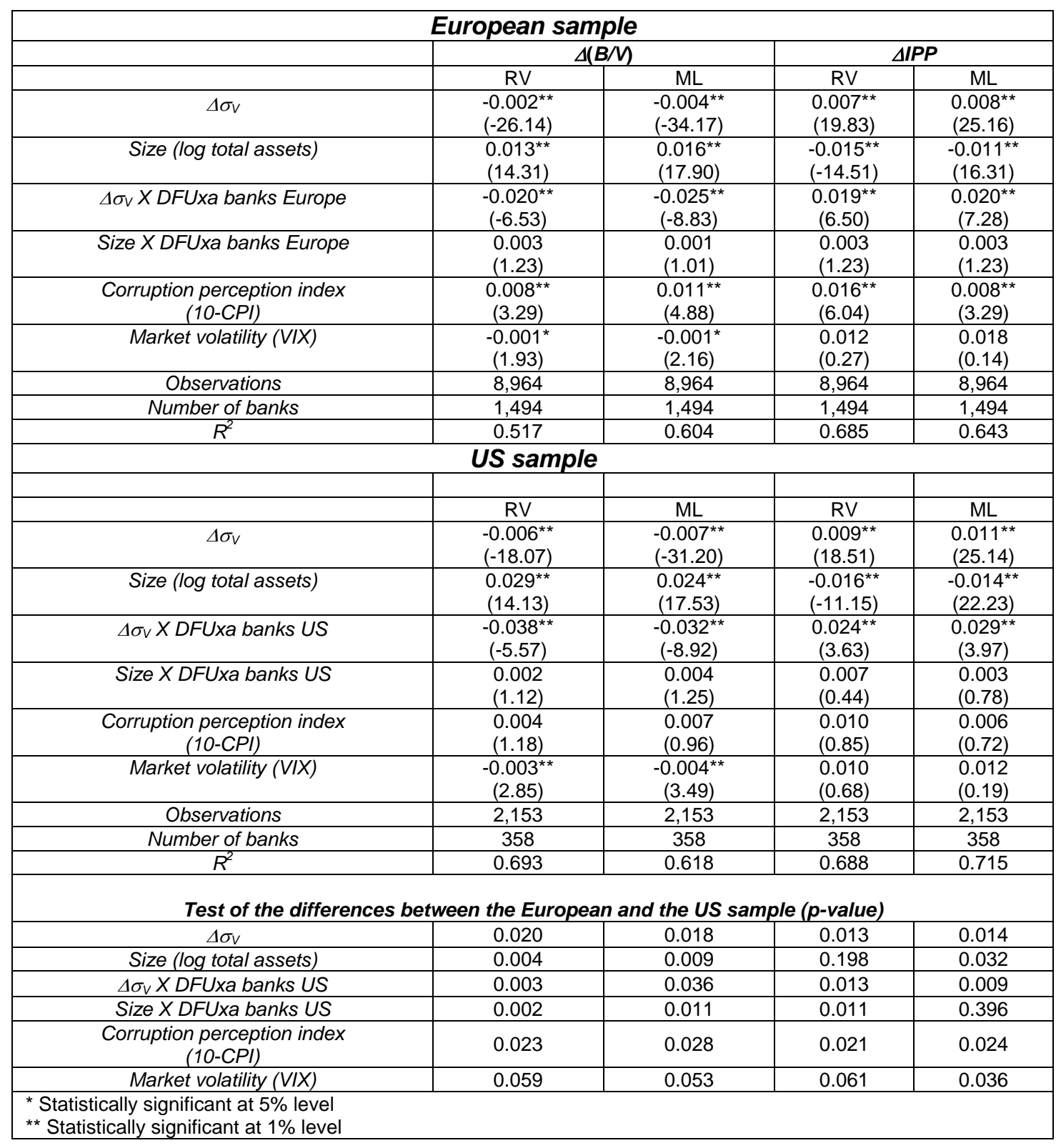




\section{TABLE 5A}

\section{SINGLE-EQUATION ESTIMATES OF THE EFFECTIVENESS OF SAFETY-NET CONTROL:} ALL BANKS AND DFUXP BANKS (BENEFITING FROM STATE AID) IN EUROPE AND IN THE US

Fixed-effects panel regressions relating changes in a bank's leverage, $\Delta B / V$, and changes in its fair insurance premium percentage, $\Delta I P P$, to changes in the volatility of its assets, $\Delta \sigma_{V} . B$ is the face value of bank's debt, including deposits. $V$ is the market value of bank assets. The errors are clustered at the firm level

\begin{tabular}{|c|c|c|c|c|}
\hline \multicolumn{5}{|c|}{ European sample } \\
\hline & \multicolumn{2}{|c|}{$\Delta(B / V)$} & \multicolumn{2}{|c|}{$\triangle I P P$} \\
\hline & RV & $\mathrm{ML}$ & RV & $\mathrm{ML}$ \\
\hline$\Delta \sigma_{V}$ & $\begin{array}{l}-0.003^{\star \star} \\
(-18.31)\end{array}$ & $\begin{array}{l}-0.005^{\star \star} \\
(-22.51)\end{array}$ & $\begin{array}{l}0.006^{\star *} \\
(14.02)\end{array}$ & $\begin{array}{l}0.007^{\star \star} \\
(33.08)\end{array}$ \\
\hline Size (log total assets) & $\begin{array}{l}0.011^{* *} \\
(12.24)\end{array}$ & $\begin{array}{l}0.014^{\star *} \\
(18.88)\end{array}$ & $\begin{array}{l}-0.013^{\star *} \\
(-17.29)\end{array}$ & $\begin{array}{l}-0.010^{\star \star} \\
(14.25)\end{array}$ \\
\hline$\Delta \sigma_{V} \times$ DFUxp banks in Europe & $\begin{array}{l}-0.009^{\star *} \\
(-7.12)\end{array}$ & $\begin{array}{l}-0.012^{\star \star} \\
(-7.31)\end{array}$ & $\begin{array}{c}0.027^{\star \star} \\
(8.15)\end{array}$ & $\begin{array}{l}0.029^{* *} \\
(6.10)\end{array}$ \\
\hline $\begin{array}{c}\text { Corruption perception index } \\
(10-C P I)\end{array}$ & $\begin{array}{c}0.010^{\star \star} \\
(2.98)\end{array}$ & $\begin{array}{c}0.011^{\star \star} \\
(4.88)\end{array}$ & $\begin{array}{c}0.016 * * \\
(6.04) \\
\end{array}$ & $\begin{array}{c}0.008^{\star *} \\
(3.29)\end{array}$ \\
\hline Market volatility (VIX) & $\begin{array}{c}-0.002^{*} \\
(2.20) \\
\end{array}$ & $\begin{array}{c}-0.007^{\star \star} \\
(2.96) \\
\end{array}$ & $\begin{array}{l}0.013 \\
(0.08) \\
\end{array}$ & $\begin{array}{l}0.011 \\
(0.19)\end{array}$ \\
\hline Observations & 8,964 & 8,964 & 8,964 & 8,964 \\
\hline Number of banks & 1,494 & 1,494 & 1,494 & 1,494 \\
\hline$R^{2}$ & 0.616 & 0.594 & 0.702 & 0.625 \\
\hline \multicolumn{5}{|c|}{ US sample } \\
\hline & RV & $\mathrm{ML}$ & RV & $\mathrm{ML}$ \\
\hline$\Delta \sigma_{V}$ & $\begin{array}{l}-0.006^{\star \star} \\
(-17.12)\end{array}$ & $\begin{array}{l}-0.008^{\star \star} \\
(-28.68)\end{array}$ & $\begin{array}{l}0.010^{\star \star} \\
(17.27)\end{array}$ & $\begin{array}{l}0.013^{\star *} \\
(22.65)\end{array}$ \\
\hline Size (log total assets) & $\begin{array}{l}0.025^{\star \star} \\
(16.77)\end{array}$ & $\begin{array}{l}0.019^{* *} \\
(14.31)\end{array}$ & $\begin{array}{l}-0.018^{\star *} \\
(-12.72)\end{array}$ & $\begin{array}{l}-0.017^{\star \star} \\
(25.90)\end{array}$ \\
\hline$\Delta \sigma_{V} X D F U x p$ banks in the US & $\begin{array}{l}-0.022^{\star \star} \\
(-6.19)\end{array}$ & $\begin{array}{l}-0.028^{\star *} \\
(-6.84)\end{array}$ & $\begin{array}{l}0.033^{*} \\
(2.14) \\
\end{array}$ & $\begin{array}{c}0.035^{\star *} \\
(4.42)\end{array}$ \\
\hline $\begin{array}{l}\text { Corruption perception index } \\
(10-C P I)\end{array}$ & $\begin{array}{l}0.003 \\
(0.82)\end{array}$ & $\begin{array}{l}0.005 \\
(0.48)\end{array}$ & $\begin{array}{l}0.014 \\
(1.12) \\
\end{array}$ & $\begin{array}{l}0.010 \\
(0.95)\end{array}$ \\
\hline Market volatility (VIX) & $\begin{array}{c}-0.006^{\star \star} \\
(3.48) \\
\end{array}$ & $\begin{array}{c}-0.005^{\star \star} \\
(3.89) \\
\end{array}$ & $\begin{array}{l}0.014 \\
(0.71)\end{array}$ & $\begin{array}{l}0.011 \\
(0.28) \\
\end{array}$ \\
\hline Observations & 2,153 & 2,153 & 2,153 & 2,153 \\
\hline Number of banks & 358 & 358 & 358 & 358 \\
\hline$R^{2}$ & 0.685 & 0.624 & 0.603 & 0.745 \\
\hline \multicolumn{5}{|c|}{ Test of the differences between the European and the US sample ( $p$-value) } \\
\hline$\Delta \sigma_{V}$ & 0.016 & 0.014 & 0.016 & 0.014 \\
\hline Size (log total assets) & 0.004 & 0.006 & 0.004 & 0.006 \\
\hline$\Delta \sigma_{V} \times$ DFUxp banks in Europe & 0.003 & 0.002 & 0.003 & 0.002 \\
\hline $\begin{array}{c}\text { Corruption perception index } \\
(10-\mathrm{CPI})\end{array}$ & 0.002 & 0.005 & 0.002 & 0.005 \\
\hline Market volatility $($ VIX) & 0.005 & 0.016 & 0.005 & 0.016 \\
\hline
\end{tabular}


TABLE 5B

SINGLE-EQUATION ESTIMATES OF THE EFFECTIVENESS OF SAFETY-NET CONTROL: ALL BANKS AND DFUXP BANKS IN EUROPE AND THE US

Fixed-effects panel regressions relating changes in a bank's leverage, $\triangle B / V$, and changes in its fair insurance premium percentage, $\triangle I P P$, to changes in the volatility of its assets, $\Delta \sigma_{v} . B$ is the face value of bank's debt, including deposits. $V$ is the market value of bank assets. The errors are clustered at the firm level

\begin{tabular}{|c|c|c|c|c|}
\hline \multicolumn{5}{|c|}{ European sample } \\
\hline & \multicolumn{2}{|c|}{$\Delta(B / V)$} & \multicolumn{2}{|c|}{$\triangle I P P$} \\
\hline & $\mathrm{RV}$ & $\mathrm{ML}$ & $\mathrm{RV}$ & $\mathrm{ML}$ \\
\hline$\Delta \sigma_{V}$ & $\begin{array}{l}-0.004^{\star *} \\
(-14.26)\end{array}$ & $\begin{array}{l}-0.006^{\star \star} \\
(-21.05)\end{array}$ & $\begin{array}{l}0.005^{\star *} \\
(13.04)\end{array}$ & $\begin{array}{l}0.007^{\star \star} \\
(28.14)\end{array}$ \\
\hline Lambda (Mills ratio) & $\begin{array}{c}-0.058^{*} \\
(1.99)\end{array}$ & $\begin{array}{l}-0.081^{\star \star} \\
(3.93)\end{array}$ & $\begin{array}{l}-0.028^{\star *} \\
(10.13)\end{array}$ & $\begin{array}{c}-0.034^{\star \star} \\
(7.82)\end{array}$ \\
\hline Size (log total assets) & $\begin{array}{l}0.010^{* *} \\
(11.51)\end{array}$ & $\begin{array}{l}0.016^{\star *} \\
(17.23)\end{array}$ & $\begin{array}{l}-0.011^{\star *} \\
(-17.50)\end{array}$ & $\begin{array}{c}-0.013^{\star *} \\
(13.85)\end{array}$ \\
\hline$\Delta \sigma_{V} \times$ DFUxp banks in Europe & $\begin{array}{c}-0.009 * * \\
(-6.14)\end{array}$ & $\begin{array}{l}-0.013^{\star \star} \\
(-7.18)\end{array}$ & $\begin{array}{l}0.029 * * \\
(8.96)\end{array}$ & $\begin{array}{c}0.025^{\star \star} \\
(5.08)\end{array}$ \\
\hline $\begin{array}{c}\text { Corruption perception index } \\
(10-C P I)\end{array}$ & $\begin{array}{c}0.011^{\star *} \\
(2.08)\end{array}$ & $\begin{array}{c}0.014^{\star \star} \\
(5.15)\end{array}$ & $\begin{array}{c}0.013^{\star *} \\
(6.17)\end{array}$ & $\begin{array}{c}0.004^{\star \star} \\
(3.22)\end{array}$ \\
\hline Market volatility (VIX) & $\begin{array}{c}-0.002^{*} \\
(2.14)\end{array}$ & $\begin{array}{c}-0.006^{\star \star} \\
(3.17)\end{array}$ & $\begin{array}{l}0.012 \\
(0.19)\end{array}$ & $\begin{array}{l}0.014 \\
(0.11)\end{array}$ \\
\hline Observations & 8,964 & 8,964 & 8,964 & 8,964 \\
\hline Number of banks & 1,494 & 1,494 & 1,494 & 1,494 \\
\hline$R^{2}$ & 0.649 & 0.629 & 0.718 & 0.632 \\
\hline \multicolumn{5}{|c|}{$\begin{array}{l}\text { FIXED-EFFECTS PROBIT SELECTION MODELS FOR ZERO-ONE BINARY VARIABLES DISTINGUISHING DFU BANKS BENEFITING FROM STATE AID (1) } \\
\text { FROM THE REST OF DFU BANKS (0) }\end{array}$} \\
\hline$\sigma_{V}$ & $\begin{array}{l}0.963^{* *} \\
(12.39)\end{array}$ & $\begin{array}{c}0.815^{* *} \\
(7.05)\end{array}$ & $\begin{array}{l}0.963^{* *} \\
(12.39)\end{array}$ & $\begin{array}{c}0.815^{* *} \\
(7.05)\end{array}$ \\
\hline Size (log total assets) & $\begin{array}{l}0.013 \\
(1.16)\end{array}$ & $\begin{array}{l}0.004 \\
(0.96)\end{array}$ & 0.013 & $\begin{array}{l}0.004 \\
(0.96)\end{array}$ \\
\hline $\begin{array}{l}\text { Corruption perception index } \\
(10-C P I)\end{array}$ & $\begin{array}{c}0.823^{* *} \\
(6.28)\end{array}$ & $\begin{array}{c}0.916^{\star *} \\
(8.62)\end{array}$ & $\begin{array}{l}0.823^{\star *} \\
(6.28)\end{array}$ & $\begin{array}{c}0.916^{\star \star} \\
(8.62)\end{array}$ \\
\hline Observations & 826 & 826 & 826 & 826 \\
\hline Number of DFUxa banks & 137 & 137 & 137 & 137 \\
\hline Number of DFUxp banks & 43 & 43 & 43 & 43 \\
\hline Log-likelihood & -626.3 & -458.5 & -626.3 & -458.5 \\
\hline Fraction of correct predictions & 88.5 & 90.4 & 88.5 & 90.4 \\
\hline \multicolumn{5}{|c|}{ US sample } \\
\hline$\Delta \sigma_{V}$ & $\begin{array}{l}-0.007^{\star *} \\
(-14.06)\end{array}$ & $-0.24 .06)$ & $\begin{array}{l}0.011^{* *} \\
(13.08)\end{array}$ & $\begin{array}{l}0.012^{\star \star} \\
(21.04)\end{array}$ \\
\hline Lambda (Mills ratio) & $\begin{array}{c}-0.094^{\star *} \\
(4.41)\end{array}$ & $\begin{array}{c}-0.078^{\star \star} \\
(5.13)\end{array}$ & $\begin{array}{c}-0.028^{\star *} \\
(6.40)\end{array}$ & $\begin{array}{c}-0.034^{\star \star} \\
(6.21)\end{array}$ \\
\hline Size (log total assets) & $\begin{array}{l}0.028^{\star \star} \\
(15.93)\end{array}$ & $\begin{array}{l}0.020^{\star \star} \\
(11.10)\end{array}$ & $\begin{array}{l}-0.016^{\star \star} \\
(-12.13)\end{array}$ & $\begin{array}{l}-0.013^{\star \star} \\
(23.03)\end{array}$ \\
\hline$\Delta \sigma_{V} \times$ DFUxp banks in the US & $\begin{array}{c}-0.021^{\star *} \\
(-7.05)\end{array}$ & $\begin{array}{c}-0.031^{\star *} \\
(-7.13)\end{array}$ & $\begin{array}{l}0.034^{*} \\
(2.10)\end{array}$ & $\begin{array}{c}0.030^{\star \star} \\
(5.06)\end{array}$ \\
\hline $\begin{array}{c}\text { Corruption perception index } \\
(10-C P I)\end{array}$ & $\begin{array}{l}0.005 \\
(0.88)\end{array}$ & $\begin{array}{l}0.006 \\
(0.51)\end{array}$ & $\begin{array}{l}0.013 \\
(1.08)\end{array}$ & $\begin{array}{l}0.009 \\
(0.72)\end{array}$ \\
\hline Market volatility (VIX) & $\begin{array}{l}-0.006^{\star *} \\
(3.20)\end{array}$ & $\begin{array}{c}-0.007^{\star *} \\
(4.13)\end{array}$ & $\begin{array}{l}0.014 \\
(0.62)\end{array}$ & $\begin{array}{l}0.012 \\
(0.33)\end{array}$ \\
\hline Observations & 2,153 & 2,153 & 2,153 & 2,153 \\
\hline Number of banks & 358 & 358 & 358 & 358 \\
\hline$R^{2}$ & 0.690 & 0.645 & 0.615 & 0.758 \\
\hline \multicolumn{5}{|c|}{$\begin{array}{l}\text { FIXED-EFFECTS PROBIT SELECTION MODELS FOR ZERO-ONE BINARY VARIABLES DISTINGUISHING DFU BANKS BENEFITING FROM STATE AID (1) } \\
\text { FROM THE REST OF DFU BANKS (0) }\end{array}$} \\
\hline$\sigma_{v}$ & $\begin{array}{l}0.703^{\star \star} \\
(18.05)\end{array}$ & $\begin{array}{l}0.626^{\star \star} \\
(12.35)\end{array}$ & $\begin{array}{l}0.703^{\star *} \\
(18.05)\end{array}$ & $\begin{array}{l}0.626^{\star *} \\
(12.35)\end{array}$ \\
\hline Size (log total assets) & $\begin{array}{c}1.624^{* *} \\
(6.51)\end{array}$ & $\begin{array}{c}1.498^{\star *} \\
(7.18)\end{array}$ & $\begin{array}{c}1.624^{* *} \\
(6.51)\end{array}$ & $\begin{array}{c}1.498^{* *} \\
(7.18)\end{array}$ \\
\hline $\begin{array}{l}\text { Corruption perception index } \\
(10-C P I)\end{array}$ & $\begin{array}{l}0.621 \\
(0.44)\end{array}$ & $\begin{array}{l}0.521 \\
(0.76)\end{array}$ & $\begin{array}{l}0.621 \\
(0.44)\end{array}$ & $\begin{array}{l}0.521 \\
(0.76)\end{array}$ \\
\hline Observations & 203 & 203 & 203 & 203 \\
\hline Number of DFUxa banks & 33 & 33 & 33 & 33 \\
\hline Number of DFUxp banks & 22 & 22 & 22 & 22 \\
\hline Log-likelihood & -484.0 & -507.2 & -484.0 & -507.2 \\
\hline Fraction of correct predictions & 89.9 & 88.5 & 89.9 & 88.5 \\
\hline
\end{tabular}


February 1, 2011

Test of the differences between the European and the US sample (p-value)

\begin{tabular}{|c|c|c|c|c|}
\hline$\Delta \sigma_{V}$ & 0.015 & 0.016 & 0.021 & 0.012 \\
\hline Size (log total assets) & 0.003 & 0.005 & 0.007 & 0.006 \\
\hline$\Delta \sigma_{V} X D F U \times p$ banks & 0.005 & 0.002 & 0.011 & 0.004 \\
\hline $\begin{array}{c}\text { Corruption perception index } \\
(10-\mathrm{CPI})\end{array}$ & 0.002 & 0.004 & 0.041 & 0.045 \\
\hline Market volatility (VIX) & 0.007 & 0.015 & 0.596 & 0.624 \\
\hline
\end{tabular}




\section{TABLE 6A}

\section{SINGLE-EQUATION ESTIMATES OF THE EFFECTIVENESS OF SAFETY-NET CONTROL: PRE-CRISIS ENVIRONMENT (2003-2006)}

Fixed-effects panel regressions relating changes in a bank's leverage, $\triangle B / V$, and changes in its fair insurance premium percentage, $\triangle I P P$, to changes in the volatility of its assets, $\Delta \sigma_{v}$. $B$ is the face value of bank's debt, including deposits. $V$ is the market value of bank assets. The errors are clustered at the firm level

\begin{tabular}{|c|c|c|c|c|}
\hline \multicolumn{5}{|c|}{ European sample } \\
\hline & \multicolumn{2}{|c|}{$\Delta(B / V)$} & \multicolumn{2}{|c|}{$\Delta I P P$} \\
\hline & RV & $\mathrm{ML}$ & RV & $\mathrm{ML}$ \\
\hline$\Delta \sigma_{V}$ & $\begin{array}{l}-0.003^{\star *} \\
(-29.47)\end{array}$ & $\begin{array}{l}-0.005^{\star \star} \\
(-33.42)\end{array}$ & $\begin{array}{l}0.005^{\star *} \\
(14.24)\end{array}$ & $\begin{array}{l}0.007^{\star \star} \\
(22.73)\end{array}$ \\
\hline Size (log total assets) & $\begin{array}{l}0.015^{\star \star} \\
(12.10)\end{array}$ & $\begin{array}{l}0.018^{\star \star} \\
(19.81)\end{array}$ & $\begin{array}{l}-0.018^{\star \star} \\
(-15.46) \\
\end{array}$ & $\begin{array}{l}-0.014^{\star \star} \\
(13.78)\end{array}$ \\
\hline$\Delta \sigma_{V} X$ DFUxa banks Europe & $\begin{array}{l}-0.029^{\star \star} \\
(-7.77)\end{array}$ & $\begin{array}{l}-0.030 \text { ** } \\
(-6.76)\end{array}$ & $\begin{array}{l}0.024^{\star \star} \\
(4.72)\end{array}$ & $\begin{array}{c}0.026^{\star \star} \\
(4.84)\end{array}$ \\
\hline $\begin{array}{l}\text { Corruption perception index } \\
(10-C P I)\end{array}$ & $\begin{array}{l}0.011^{\star *} \\
(5.18)\end{array}$ & $\begin{array}{l}0.005^{\star *} \\
(4.93)\end{array}$ & $\begin{array}{l}0.011^{\star *} \\
(5.91)\end{array}$ & $\begin{array}{l}0.007^{\star *} \\
(4.58)\end{array}$ \\
\hline Market volatility $($ VIX) & $\begin{array}{c}-0.001^{\star} \\
(2.19)\end{array}$ & $\begin{array}{c}-0.001^{\star \star} \\
(2.84)\end{array}$ & $\begin{array}{l}0.018 \\
(0.52)\end{array}$ & $\begin{array}{l}0.025 \\
(0.27)\end{array}$ \\
\hline Observations & 6,156 & 6,156 & 6,156 & 6,156 \\
\hline Number of banks & 1,539 & 1,539 & 1,539 & 1,539 \\
\hline$R^{2}$ & 0.517 & 0.562 & 0.597 & 0.534 \\
\hline \multicolumn{5}{|c|}{ US sample } \\
\hline & & & & \\
\hline & RV & $\mathrm{ML}$ & RV & $\mathrm{ML}$ \\
\hline$\Delta \sigma_{V}$ & $\begin{array}{l}-0.005^{\star \star} \\
(-16.35)\end{array}$ & $\begin{array}{l}-0.009^{* *} \\
(-24.15)\end{array}$ & $\begin{array}{l}0.011^{\star *} \\
(12.16)\end{array}$ & $\begin{array}{l}0.013^{\star \star} \\
(16.31)\end{array}$ \\
\hline Size (log total assets) & $\begin{array}{l}0.037^{\star \star} \\
(15.56)\end{array}$ & $\begin{array}{l}0.032^{\star \star} \\
(16.74)\end{array}$ & $\begin{array}{l}-0.013^{\star \star} \\
(-14.20) \\
\end{array}$ & $\begin{array}{l}-0.011^{\star *} \\
(18.26)\end{array}$ \\
\hline$\Delta \sigma_{V} X$ DFUxa banks US & $\begin{array}{l}-0.041^{*} \\
(-2.21)\end{array}$ & $\begin{array}{l}-0.035^{\star \star} \\
(-2.19)\end{array}$ & $\begin{array}{l}0.032^{\star \star} \\
(5.84)\end{array}$ & $\begin{array}{l}0.034^{\star \star} \\
(3.13)\end{array}$ \\
\hline $\begin{array}{l}\text { Corruption perception index } \\
(10-C P I)\end{array}$ & $\begin{array}{l}0.002 \\
(0.77)\end{array}$ & $\begin{array}{l}0.003 \\
(0.53)\end{array}$ & $\begin{array}{l}0.012 \\
(0.97)\end{array}$ & $\begin{array}{l}0.008 \\
(0.68)\end{array}$ \\
\hline Market volatility $($ VIX) & $\begin{array}{c}-0.004^{\star *} \\
(3.99)\end{array}$ & $\begin{array}{c}-0.005^{\star \star} \\
(5.18)\end{array}$ & $\begin{array}{l}0.008 \\
(0.76)\end{array}$ & $\begin{array}{l}0.018 \\
(0.21)\end{array}$ \\
\hline Observations & 1,398 & 1,398 & 1,398 & 1,398 \\
\hline Number of banks & 349 & 349 & 349 & 349 \\
\hline$R^{2}$ & 0.584 & 0.494 & 0.652 & 0.626 \\
\hline \multicolumn{5}{|c|}{ Test of the differences between the European and the US sample ( $p$-value) } \\
\hline$\Delta \sigma_{V}$ & 0.014 & 0.011 & 0.015 & 0.012 \\
\hline Size (log total assets) & 0.002 & 0.003 & 0.006 & 0.026 \\
\hline$\Delta \sigma_{V} \times D F U x a$ banks Europe & 0.003 & 0.031 & 0.078 & 0.003 \\
\hline $\begin{array}{c}\text { Corruption perception index } \\
(10-\mathrm{CPI})\end{array}$ & 0.006 & 0.031 & 0.362 & 0.408 \\
\hline Market volatility $(\mathrm{VIX})$ & 0.023 & 0.013 & 0.014 & 0.008 \\
\hline
\end{tabular}




\section{TABLE 6B}

\section{SINGLE-EQUATION ESTIMATES OF THE EFFECTIVENESS OF SAFETY-NET CONTROL: CRISIS ENVIRONMENT (2007-2008)}

Fixed-effects panel regressions relating changes in a bank's leverage, $\triangle B / N$, and changes in its fair insurance premium percentage, $\triangle I P P$, to changes in the volatility of its assets, $\Delta \sigma_{v}$. B is the face value of bank's debt, including deposits. $V$ is the market value of bank assets. The errors are clustered at the firm level.

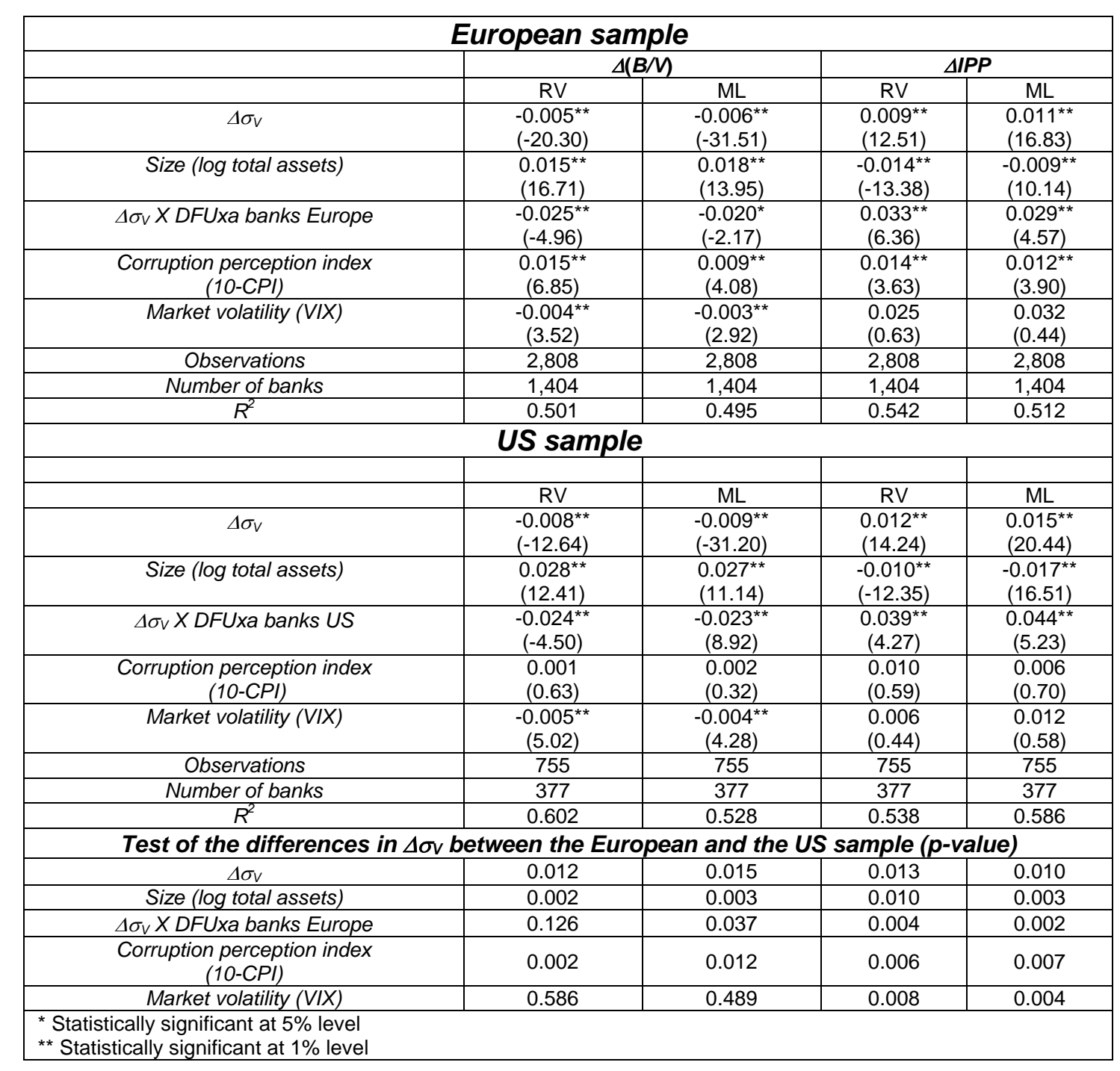


TABLE 7

TESTS OF DIFFERENCES BETWEEN PRECRISIS (2003-2006) AND CRISIS YEARS (20072008) FOR THE US AND EUROPE SEPARATELY

The table shows p-values of covariance tests for coefficient differences as well as the F-test of the overall differences between the sub-samples

\begin{tabular}{|c|c|c|c|c|}
\hline \multicolumn{5}{|c|}{ European sample } \\
\hline & \multicolumn{2}{|c|}{$\Delta(B / M)$} & \multicolumn{2}{|c|}{$\triangle I P P$} \\
\hline & RV & $\mathrm{ML}$ & RV & $\mathrm{ML}$ \\
\hline$\Delta \sigma_{V}$ & 0.023 & 0.042 & 0.007 & 0.012 \\
\hline Size (log total assets) & 0.653 & 0.728 & 0.046 & 0.007 \\
\hline$\Delta \sigma_{V} \times$ DFUxa banks Europe & 0.124 & 0.005 & 0.006 & 0.138 \\
\hline $\begin{array}{l}\text { Corruption perception index } \\
(10-\mathrm{CPI})\end{array}$ & 0.014 & 0.011 & 0.088 & 0.005 \\
\hline Market volatility (VIX) & 0.009 & 0.016 & 0.008 & 0.018 \\
\hline Overall coefficients F-test & 0.018 & 0.013 & 0.011 & 0.016 \\
\hline \multicolumn{5}{|c|}{ US sample } \\
\hline & \multicolumn{2}{|c|}{$\Delta(B / M)$} & \multicolumn{2}{|c|}{$\triangle I P P$} \\
\hline & $\mathrm{RV}$ & ML & $\mathrm{RV}$ & ML \\
\hline$\Delta \sigma_{V}$ & 0.046 & 0.196 & 0.140 & 0.051 \\
\hline Size (log total assets) & 0.007 & 0.006 & 0.013 & 0.004 \\
\hline$\Delta \sigma_{V} \times D F U x a$ banks US & 0.003 & 0.008 & 0.053 & 0.009 \\
\hline $\begin{array}{c}\text { Corruption perception index } \\
(10-C P I)\end{array}$ & 0.963 & 0.694 & 0.121 & 0.160 \\
\hline Market volatility (VIX) & 0.864 & 0.658 & 0.134 & 0.079 \\
\hline Overall coefficients F-test & 0.019 & 0.034 & 0.038 & 0.030 \\
\hline
\end{tabular}


TABLE 8A

SINGLE-EQUATION ESTIMATES OF THE EFFECTIVENESS OF SAFETY-NET CONTROL: ALL BANKS AND DFUXP BANKS IN EUROPE AND IN THE US

PRE-CRISIS ENVIRONMENT (2003-2006)

Fixed-effects panel regressions relating changes in a bank's leverage, $\triangle B / V$, and changes in its fair insurance premium percentage, $\triangle I P P$, to changes in the riskiness of its assets, $\Delta \sigma_{v} . B$ is the face value of bank's debt, including deposits. $V$ is the market value of bank assets. The errors are clustered at the firm level

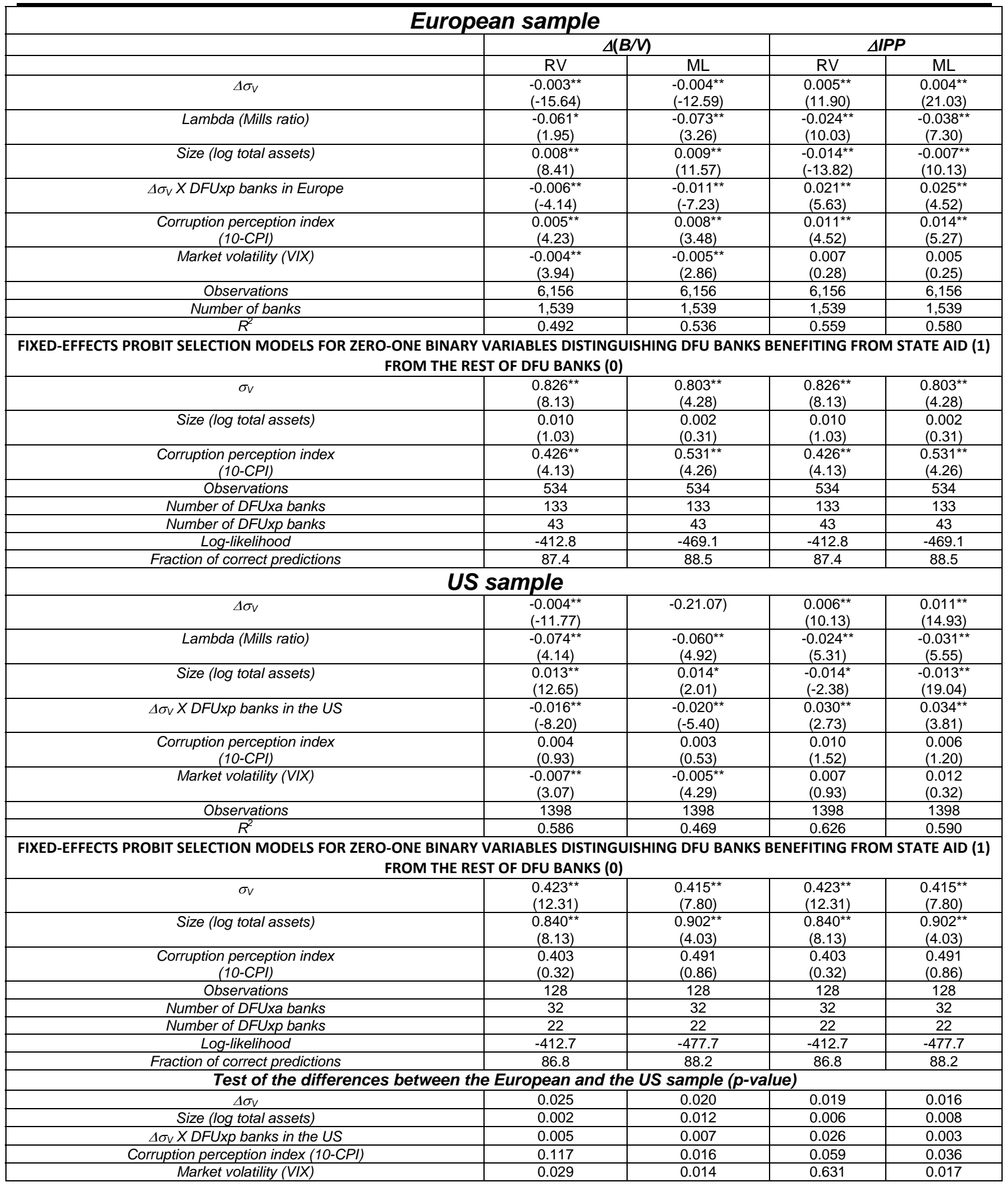


February 1, 2011

Test of the differences between the selection equations for the European and the US sample ( $p$-value)

\begin{tabular}{|c|c|c|c|c|}
\hline$\sigma_{V}$ & 0.002 & 0.001 & 0.003 & 0.004 \\
\hline Size (log total assets) & 0.001 & 0.002 & 0.001 & 0.001 \\
\hline Corruption perception index (10-CPI) & 0.013 & 0.019 & 0.003 & 0.001 \\
\hline * Statistically significant at 5\% level &
\end{tabular}

Statistically significant at $5 \%$ level 
TABLE 8B

SINGLE-EQUATION ESTIMATES OF THE EFFECTIVENESS OF SAFETY-NET CONTROL: ALL BANKS AND DFUXP BANKS IN EUROPE AND IN THE US

DURING CRISIS YEARS (2007-2008)

Fixed-effects panel regressions relating changes in a bank's leverage, $\triangle B / V$, and changes in its fair insurance premium percentage, $\triangle I P P$, to changes in the riskiness of its assets, $\Delta \sigma_{v} . B$ is the face value of bank's debt, including deposits. $V$ is the market value of bank assets. The errors are clustered at the firm level

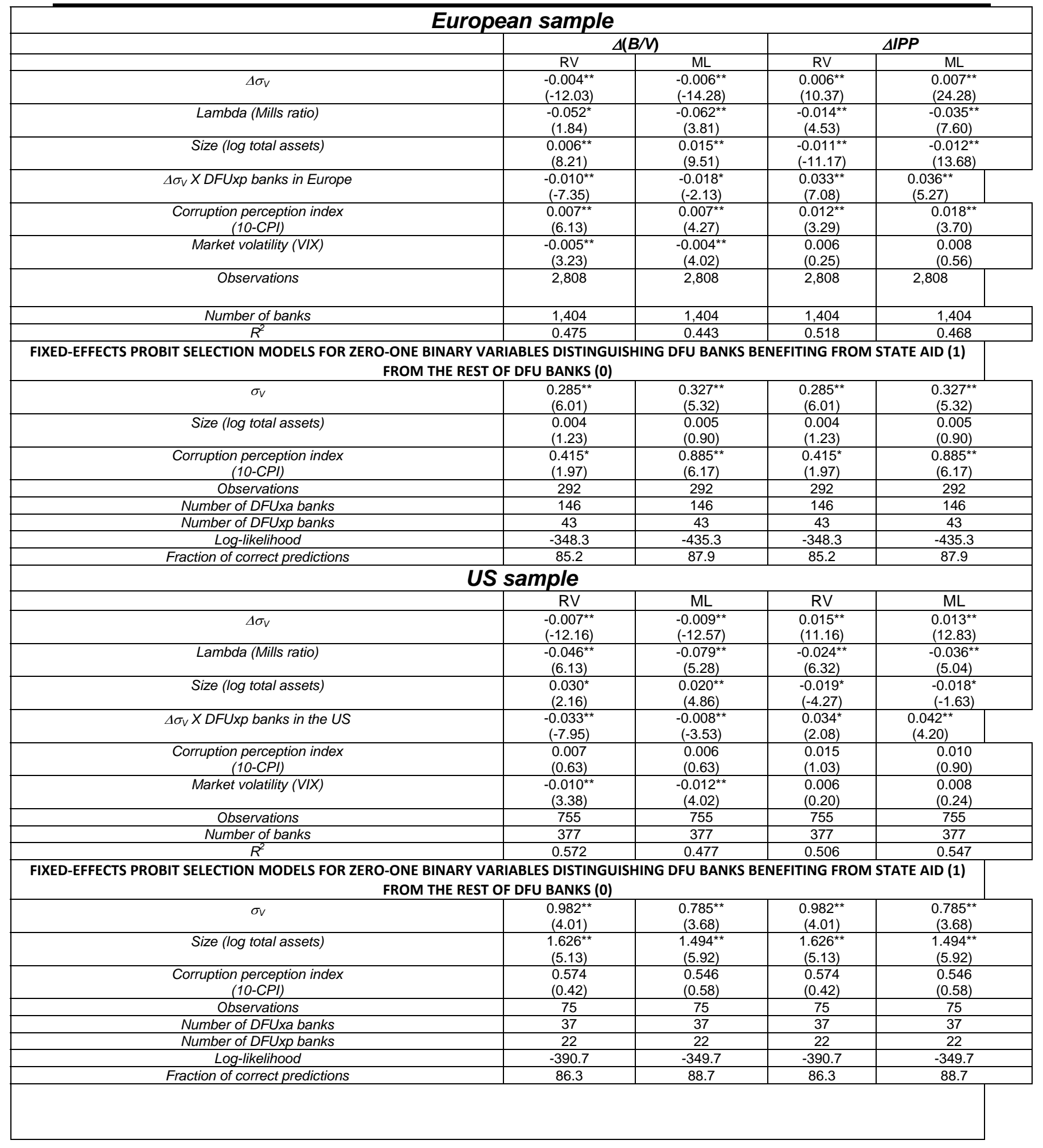


February 1, 2011

\begin{tabular}{|c|c|c|c|c|}
\hline \multicolumn{5}{|c|}{ Test of the differences between the European and the US sample ( $p$-value) } \\
\hline$\Delta \sigma_{v}$ & 0.020 & 0.018 & 0.015 & 0.013 \\
\hline Size (log total assets) & 0.003 & 0.006 & 0.004 & 0.007 \\
\hline$\Delta \sigma_{V} \times$ DFUxp banks in the US & 0.005 & 0.003 & 0.044 & 0.038 \\
\hline Corruption perception index (10-CPI) & 0.705 & 0.020 & 0.029 & 0.027 \\
\hline Market volatility $(\mathrm{VIX})$ & 0.013 & 0.014 & 0.657 & 0.266 \\
\hline \multicolumn{5}{|c|}{ Test of the differences between the selection equations for the European and the US sample ( $p$-value) } \\
\hline$\sigma_{V}$ & 0.001 & 0.001 & 0.001 & 0.001 \\
\hline Size (log total assets) & 0.001 & 0.001 & 0.001 & 0.001 \\
\hline Corruption perception index (10-CPI) & 0.023 & 0.006 & 0.002 & 0.002 \\
\hline
\end{tabular}




\section{TABLE 9}

\section{TESTS OF THE DIFFERENCES BETWEEN THE PRECRISIS (2003-2006) AND CRISIS} YEARS (2007-2008): DFUxp BANKS IN EUROPE AND THE US

The table show the $p$-values of the tests for coefficient differences as well as the F-test of the overall differences between the subsamples

\begin{tabular}{|c|c|c|c|c|}
\hline \multicolumn{5}{|c|}{ European sample } \\
\hline & \multicolumn{2}{|c|}{$\Delta(B / M)$} & \multicolumn{2}{|c|}{$\Delta I P P$} \\
\hline & RV & $\mathrm{ML}$ & RV & $\mathrm{ML}$ \\
\hline$\Delta \sigma_{V}$ & 0.006 & 0.012 & 0.006 & 0.003 \\
\hline Size (log total assets) & 0.011 & 0.004 & 0.107 & 0.052 \\
\hline$\Delta \sigma_{V} \times$ DFUxp banks in Europe & 0.008 & 0.009 & 0.004 & 0.006 \\
\hline $\begin{array}{c}\text { Corruption perception index } \\
(10-\mathrm{CPI})\end{array}$ & 0.019 & 0.294 & 0.013 & 0.011 \\
\hline Market volatility (VIX) & 0.048 & 0.031 & 0.002 & 0.003 \\
\hline Overall coefficients F-test & 0.010 & 0.013 & 0.008 & 0.009 \\
\hline \multicolumn{5}{|c|}{ US sample } \\
\hline & \multicolumn{2}{|c|}{$\Delta(B / V)$} & \multicolumn{2}{|c|}{$\triangle I P P$} \\
\hline & $\mathrm{RV}$ & $\mathrm{ML}$ & $\mathrm{RV}$ & $\mathrm{ML}$ \\
\hline$\Delta \sigma_{V}$ & 0.005 & 0.011 & 0.004 & 0.003 \\
\hline Size (log total assets) & 0.003 & 0.003 & 0.003 & 0.004 \\
\hline$\Delta \sigma_{V} X D F U x p$ banks in the US & 0.004 & 0.005 & 0.005 & 0.128 \\
\hline $\begin{array}{l}\text { Corruption perception index } \\
(10-\mathrm{CPI})\end{array}$ & 0.043 & 0.238 & 0.013 & 0.029 \\
\hline Market volatility (VIX) & 0.031 & 0.011 & 0.002 & 0.003 \\
\hline Overall coefficients F-test & 0.008 & 0.010 & 0.006 & 0.008 \\
\hline
\end{tabular}


TABLE 10A

SINGLE-EQUATION ESTIMATES OF THE EFFECTIVENESS OF SAFETY-NET CONTROL: PORTUGAL AND IRELAND

Fixed-effects panel regressions relating changes in a bank's leverage, $\Delta B / V$, and changes in its fair insurance premium percentage, $\triangle I P P$, to changes in the riskiness of its assets, $\Delta \sigma_{V} . B$ is the face value of bank's debt, including deposits. $V$ is the market value of bank assets. The errors are clustered at the firm level

\begin{tabular}{|c|c|c|c|c|}
\hline \multicolumn{5}{|c|}{ Portugal } \\
\hline & \multicolumn{2}{|c|}{$\Delta(B / V)$} & \multicolumn{2}{|c|}{$\triangle I P P$} \\
\hline & RV & $\mathrm{ML}$ & RV & $\mathrm{ML}$ \\
\hline$\Delta \sigma_{V}$ & $\begin{array}{c}-0.003^{\star *} \\
(-8.64) \\
\end{array}$ & $\begin{array}{l}-0.004^{\star \star} \\
(-22.16) \\
\end{array}$ & $\begin{array}{l}0.011^{\star *} \\
(10.51) \\
\end{array}$ & $\begin{array}{l}0.010^{\star *} \\
(9.87)\end{array}$ \\
\hline Lambda (Mills ratio) & $\begin{array}{c}-0.043^{\star \star} \\
(2.98)\end{array}$ & $\begin{array}{l}-0.071^{\star *} \\
(5.53)\end{array}$ & $\begin{array}{l}-0.019^{\star \star} \\
(6.18)\end{array}$ & $\begin{array}{c}-0.024^{\star \star} \\
(5.96)\end{array}$ \\
\hline Size (log total assets) & $\begin{array}{l}0.006^{\star \star} \\
(11.13)\end{array}$ & $\begin{array}{l}0.008^{\star \star} \\
(13.82)\end{array}$ & $\begin{array}{l}-0.014^{\star *} \\
(-9.32)\end{array}$ & $\begin{array}{l}-0.013^{\star \star} \\
(12.63)\end{array}$ \\
\hline$\Delta \sigma_{V} \times$ DFUxp banks in Portugal & $\begin{array}{l}-0.012^{\star *} \\
(-3.98)\end{array}$ & $\begin{array}{c}-0.015^{\star \star} \\
(-5.83)\end{array}$ & $\begin{array}{c}0.038^{\star \star} \\
(2.94)\end{array}$ & $\begin{array}{l}0.030^{\star \star} \\
(2.61)\end{array}$ \\
\hline $\begin{array}{c}\text { Corruption perception index } \\
(10-\mathrm{CPI})\end{array}$ & $\begin{array}{c}0.010^{\star *} \\
(3.31)\end{array}$ & $\begin{array}{c}0.009^{* *} \\
(2.31)\end{array}$ & $\begin{array}{c}0.014^{\star *} \\
(5.02)\end{array}$ & $\begin{array}{c}0.011^{\star *} \\
(3.36)\end{array}$ \\
\hline Market volatility $(V I X)$ & $\begin{array}{l}-0.004 \\
(1.03) \\
\end{array}$ & $\begin{array}{l}-0.003 \\
(1.27) \\
\end{array}$ & $\begin{array}{l}0.005 \\
(0.33) \\
\end{array}$ & $\begin{array}{l}0.003 \\
(0.28) \\
\end{array}$ \\
\hline Observations & 158 & 158 & 158 & 158 \\
\hline Number of banks & 26 & 26 & 26 & 26 \\
\hline$R^{2}$ & 0.403 & 0.460 & 0.484 & 0.520 \\
\hline \multicolumn{5}{|c|}{ FIXED-EFFECTS PROBIT SELECTION MODELS FOR ZERO-ONE BINARY VARIABLES DISTINGUISHING DFU BANKS BENEFITING FROM STATE AID (1 } \\
\hline \multicolumn{5}{|c|}{ FROM THE REST OF DFU BANKS (0) } \\
\hline$\sigma_{V}$ & $\begin{array}{c}0.423^{\star \star} \\
(5.18)\end{array}$ & $\begin{array}{c}0.432^{\star \star} \\
(6.15)\end{array}$ & $\begin{array}{c}0.423^{\star \star} \\
(5.18)\end{array}$ & $\begin{array}{c}0.432^{\star \star} \\
(6.15)\end{array}$ \\
\hline Size (log total assets) & $\begin{array}{l}0.026 \\
(1.63)\end{array}$ & $\begin{array}{l}0.012 \\
(0.94)\end{array}$ & $\begin{array}{l}0.026 \\
(1.63)\end{array}$ & $\begin{array}{l}0.012 \\
(0.94)\end{array}$ \\
\hline $\begin{array}{c}\text { Corruption perception index } \\
(10-\mathrm{CPI})\end{array}$ & $\begin{array}{l}0.661^{*} \\
(2.23) \\
\end{array}$ & $\begin{array}{c}0.891^{\star *} \\
(6.02)\end{array}$ & $\begin{array}{l}0.661^{*} \\
(2.23) \\
\end{array}$ & $\begin{array}{l}0.891^{\star \star} \\
(6.02)\end{array}$ \\
\hline Observations & 24 & 24 & 24 & 24 \\
\hline Number of DFUxa banks & 4 & 4 & 4 & 4 \\
\hline Number of DFUxp banks & 2 & 2 & 2 & 2 \\
\hline Log-likelihood & -326.7 & -460.3 & -326.7 & -460.3 \\
\hline Fraction of correct predictions & 86.4 & 88.4 & 86.4 & 88.4 \\
\hline \multicolumn{5}{|c|}{ Ireland } \\
\hline & RV & $\mathrm{ML}$ & RV & $\mathrm{ML}$ \\
\hline$\Delta \sigma_{V}$ & $\begin{array}{l}-0.002^{\star \star} \\
(-11.01)\end{array}$ & $\begin{array}{l}-0.002^{\star \star} \\
(-16.50)\end{array}$ & $\begin{array}{l}0.015^{\star \star} \\
(13.08)\end{array}$ & $\begin{array}{l}0.018^{\star \star} \\
(14.82)\end{array}$ \\
\hline Lambda (Mills ratio) & $\begin{array}{c}-0.039^{\star} \\
(2.63)\end{array}$ & $\begin{array}{c}-0.050^{\star \star} \\
(4.09)\end{array}$ & $\begin{array}{l}-0.028^{\star \star} \\
(6.08)\end{array}$ & $\begin{array}{c}-0.042^{\star \star} \\
(9.02)\end{array}$ \\
\hline Size (log total assets) & $\begin{array}{l}0.023^{\star *} \\
(12.60)\end{array}$ & $\begin{array}{l}0.013^{\star *} \\
(19.42)\end{array}$ & $\begin{array}{l}-0.018^{\star \star} \\
(-10.09)\end{array}$ & $\begin{array}{c}-0.020^{\star *} \\
(14.37)\end{array}$ \\
\hline$\Delta \sigma_{V} \times D F U x p$ banks in Ireland & $\begin{array}{c}-0.018^{\star *} \\
(-6.54)\end{array}$ & $\begin{array}{c}-0.019^{\star *} \\
(-3.88)\end{array}$ & $\begin{array}{c}0.049^{* *} \\
(3.62)\end{array}$ & $\begin{array}{c}0.064^{\star *} \\
(4.03)\end{array}$ \\
\hline $\begin{array}{c}\text { Corruption perception index } \\
(10-C P I)\end{array}$ & $\begin{array}{c}0.084^{\star *} \\
(5.23)\end{array}$ & $\begin{array}{c}0.041^{\star *} \\
(5.03)\end{array}$ & $\begin{array}{l}0.018^{\star *} \\
(5.21)\end{array}$ & $\begin{array}{c}0.021^{\star \star} \\
(5.52)\end{array}$ \\
\hline Market volatility (VIX) & $\begin{array}{l}-0.006 \\
(1.32)\end{array}$ & $\begin{array}{l}-0.005 \\
(1.62)\end{array}$ & $\begin{array}{l}0.016 \\
(0.40)\end{array}$ & $\begin{array}{l}0.019 \\
(0.28)\end{array}$ \\
\hline Observations & 157 & 157 & 157 & 157 \\
\hline Number of banks & 25 & 25 & 25 & 25 \\
\hline$R^{2}$ & 0.447 & 0.416 & 0.593 & 0.496 \\
\hline \multicolumn{5}{|c|}{$\begin{array}{c}\text { FIXED-EFFECTS PROBIT SELECTION MODELS FOR ZERO-ONE BINARY VARIABLES DISTINGUISHING DFU BANKS BENEFITING FROM STATE AID (1) FROM THE REST } \\
\text { OF DFU BANKS (0) }\end{array}$} \\
\hline$\sigma_{V}$ & $\begin{array}{c}0.225^{\star \star} \\
(4.36)\end{array}$ & $\begin{array}{c}0.212^{\star \star} \\
(5.28)\end{array}$ & $\begin{array}{c}0.225^{\star \star} \\
(4.36)\end{array}$ & $\begin{array}{c}0.212^{\star *} \\
(5.28)\end{array}$ \\
\hline Size (log total assets) & $\begin{array}{l}0.096^{*} \\
(2.13) \\
\end{array}$ & $\begin{array}{l}0.077^{*} \\
(4.82)\end{array}$ & $\begin{array}{l}0.096^{*} \\
(2.13)\end{array}$ & $\begin{array}{l}0.077^{*} \\
(4.82)\end{array}$ \\
\hline $\begin{array}{l}\text { Corruption perception index } \\
(10-C P I)\end{array}$ & $\begin{array}{l}0.686^{\star \star} \\
(2.91)\end{array}$ & 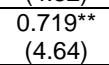 & $\begin{array}{l}0.686^{\star \star} \\
(2.91)\end{array}$ & $\begin{array}{l}0.719^{* *} \\
(4.64)\end{array}$ \\
\hline Observations & 24 & 24 & 24 & 24 \\
\hline Number of DFUxa banks & 4 & 4 & 4 & 4 \\
\hline Number of DFUxp banks & 3 & 3 & 3 & 3 \\
\hline Log-likelihood & -3263 & -412.0 & -3263 & -412.0 \\
\hline Fraction of correct predictions & 83.7 & 85.3 & 83.7 & 85.3 \\
\hline
\end{tabular}


TABLE 10B

SINGLE-EQUATION ESTIMATES OF THE EFFECTIVENESS OF SAFETY-NET CONTROL: SPAIN AND ITALY

Fixed-effects panel regressions relating changes in a bank's leverage, $\Delta B / V$, and changes in its fair insurance premium percentage, $\triangle I P P$, to changes in the riskiness of its assets, $\Delta \sigma_{\mathrm{V}} . B$ is the face value of bank's debt, including deposits. $V$ is the market value of bank assets. The errors are clustered at the firm level

\begin{tabular}{|c|c|c|c|c|}
\hline \multicolumn{5}{|c|}{ Spain } \\
\hline & \multicolumn{2}{|c|}{$\Delta(B / V)$} & \multicolumn{2}{|c|}{$\Delta I P P$} \\
\hline & RV & $\mathrm{ML}$ & RV & $\mathrm{ML}$ \\
\hline$\Delta \sigma_{V}$ & $\begin{array}{l}-0.004^{\star *} \\
(-15.04)\end{array}$ & $\begin{array}{l}-0.005^{\star \star} \\
(-25.18)\end{array}$ & $\begin{array}{l}0.006^{\star *} \\
(16.12)\end{array}$ & $\begin{array}{l}0.008^{\star *} \\
(16.27)\end{array}$ \\
\hline Lambda (Mills ratio) & $\begin{array}{l}-0.021^{\star *} \\
(4.88)\end{array}$ & $\begin{array}{c}-0.025^{\star \star} \\
(6.58)\end{array}$ & $\begin{array}{c}-0.016^{\star *} \\
(3.31)\end{array}$ & $\begin{array}{c}-0.014^{\star \star} \\
(4.19)\end{array}$ \\
\hline Size (log total assets) & $\begin{array}{l}0.037 \\
(0.85)\end{array}$ & $\begin{array}{l}0.027 \\
(0.31)\end{array}$ & $\begin{array}{l}0.012 \\
(0.63)\end{array}$ & $\begin{array}{l}0.010 \\
(0.40) \\
\end{array}$ \\
\hline $\begin{array}{c}\text { Corruption perception index } \\
(10-\mathrm{CPI})\end{array}$ & $\begin{array}{l}0.004^{\star \star} \\
(3.18)\end{array}$ & $\begin{array}{l}0.003^{\star \star} \\
(2.58)\end{array}$ & $\begin{array}{c}0.007^{\star \star} \\
(5.01)\end{array}$ & $\begin{array}{l}0.008^{\star \star} \\
(3.14)\end{array}$ \\
\hline Market volatility $($ VIX) & $\begin{array}{l}-0.002 \\
(0.73)\end{array}$ & $\begin{array}{l}-0.001 \\
(0.34)\end{array}$ & $\begin{array}{l}0.005 \\
(0.20)\end{array}$ & $\begin{array}{l}0.004 \\
(0.33)\end{array}$ \\
\hline Observations & 531 & 531 & 531 & 531 \\
\hline Number of banks & 86 & 86 & 86 & 86 \\
\hline$R^{2}$ & 0.503 & 0.550 & 0.519 & 0.523 \\
\hline \multicolumn{5}{|c|}{ FROM THE REST OF DFU BANKS (0) } \\
\hline$\sigma_{V}$ & $\begin{array}{l}0.131^{\star \star} \\
(4.56)\end{array}$ & $\begin{array}{l}0.131^{\star \star} \\
(5.01)\end{array}$ & $\begin{array}{c}0.131^{* *} \\
(4.56)\end{array}$ & $\begin{array}{c}0.131^{* *} \\
(5.01)\end{array}$ \\
\hline Size (log total assets) & $\begin{array}{l}0.008 \\
(0.55) \\
\end{array}$ & $\begin{array}{l}0.009 \\
(0.65) \\
\end{array}$ & $\begin{array}{l}0.008 \\
(0.55) \\
\end{array}$ & $\begin{array}{l}0.009 \\
(0.65) \\
\end{array}$ \\
\hline $\begin{array}{c}\text { Corruption perception index } \\
(10-\mathrm{CPI})\end{array}$ & $\begin{array}{c}0.285^{\star *} \\
(2.76)\end{array}$ & $\begin{array}{l}0.826^{\star *} \\
(6.04)\end{array}$ & $\begin{array}{c}0.285^{\star *} \\
(2.76)\end{array}$ & $\begin{array}{l}0.826^{\star *} \\
(6.04)\end{array}$ \\
\hline Observations & 52 & 52 & 52 & 52 \\
\hline Number of DFUxa banks & 8 & 8 & 8 & 8 \\
\hline Number of DFUxp banks & 4 & 4 & 4 & 4 \\
\hline Log-likelihood & -318.5 & -401.7 & -318.5 & -401.7 \\
\hline Fraction of correct predictions & 83.7 & 84.2 & 83.7 & 84.2 \\
\hline \multicolumn{5}{|c|}{ Italy } \\
\hline$\Delta \sigma_{V}$ & $\begin{array}{l}-0.007^{\star \star} \\
(-10.13)\end{array}$ & $\begin{array}{l}-0.008^{\star \star} \\
(-15.06)\end{array}$ & $\begin{array}{l}0.008^{\star \star} \\
(16.67)\end{array}$ & $\begin{array}{l}0.006^{\star \star} \\
(12.34)\end{array}$ \\
\hline Lambda (Mills ratio) & $\begin{array}{c}-0.059^{\star} \\
(2.31) \\
\end{array}$ & $\begin{array}{l}-0.063^{*} \\
(2.13)\end{array}$ & $\begin{array}{c}-0.052^{* *} \\
(4.83)\end{array}$ & $\begin{array}{l}-0.060^{\star *} \\
(7.15)\end{array}$ \\
\hline Size (log total assets) & $\begin{array}{l}0.032^{\star \star} \\
(13.84)\end{array}$ & $\begin{array}{l}0.038^{\star *} \\
(14.13)\end{array}$ & $\begin{array}{c}-0.029^{* \star} \\
(-7.15)\end{array}$ & $\begin{array}{c}-0.010^{\star \star} \\
(14.32)\end{array}$ \\
\hline $\begin{array}{c}\text { Corruption perception index } \\
(10-\mathrm{CPI})\end{array}$ & $\begin{array}{c}0.008^{\star *} \\
(4.83)\end{array}$ & $\begin{array}{l}0.006^{\star *} \\
(4.94)\end{array}$ & $\begin{array}{c}0.005^{\star *} \\
(3.34)\end{array}$ & $\begin{array}{c}0.006^{* *} \\
(4.05)\end{array}$ \\
\hline Market volatility (VIX) & $\begin{array}{l}-0.001 \\
(0.30)\end{array}$ & $\begin{array}{l}-0.002 \\
(0.35)\end{array}$ & $\begin{array}{l}0.003 \\
(0.62)\end{array}$ & $\begin{array}{l}0.004 \\
(0.30)\end{array}$ \\
\hline Observations & 1236 & 1236 & 1236 & 1236 \\
\hline Number of DFU banks & 206 & 206 & 206 & 206 \\
\hline$R^{2}$ & 0.576 & 0.593 & 0.580 & 0.613 \\
\hline \multirow{2}{*}{\multicolumn{5}{|c|}{ FIXED-EFFECTS PROBIT SELECTION MODELS FOR ZERO-ONE BINARY VARIABLES DISTINGUISHING DFU BANKS BENEFITING FROM STATE AID (1 }} \\
\hline & & & & \\
\hline$\sigma_{V}$ & $\begin{array}{l}0.721^{\star \star} \\
(7.58)\end{array}$ & $\begin{array}{l}0.850^{\star \star} \\
(4.16)\end{array}$ & $\begin{array}{c}0.721^{\star \star} \\
(7.58)\end{array}$ & $\begin{array}{c}0.850^{\star \star} \\
(4.16)\end{array}$ \\
\hline Size (log total assets) & $\begin{array}{l}0.013^{\star} \\
(1.96)\end{array}$ & $\begin{array}{l}0.010^{\star \star} \\
(3.05)\end{array}$ & $\begin{array}{l}0.013^{\star} \\
(1.96)\end{array}$ & $\begin{array}{c}0.010^{\star \star} \\
(3.05)\end{array}$ \\
\hline $\begin{array}{c}\text { Corruption perception index } \\
(10-\mathrm{CPI})\end{array}$ & $\begin{array}{l}0.421^{\star *} \\
(3.75)\end{array}$ & $\begin{array}{c}0.478^{\star *} \\
(4.01)\end{array}$ & $\begin{array}{c}0.421^{\star *} \\
(3.75)\end{array}$ & $\begin{array}{c}0.478^{\star *} \\
(4.01)\end{array}$ \\
\hline Observations & 120 & 120 & 120 & 120 \\
\hline Number of DFUxa banks & 20 & 20 & 20 & 20 \\
\hline Number of DFUxp banks & 6 & 6 & 6 & 6 \\
\hline Log-likelihood & -360.5 & -390.0 & -360.5 & -390.0 \\
\hline Fraction of correct predictions & 85.0 & 86.5 & 85.0 & 86.5 \\
\hline
\end{tabular}


TABLE 10C

TESTS OF THE DIFFERENCES BETWEEN PORTUGAL, IRELAND, SPAIN AND ITALY DFUxp BANKS

p-values in parentheses

\begin{tabular}{|c|c|c|c|c|}
\hline \multicolumn{5}{|c|}{ Test of the differences between Portugal and Ireland } \\
\hline$\Delta \sigma_{V}$ & 0.057 & 0.046 & 0.026 & 0.022 \\
\hline Size (log total assets) & 0.016 & 0.010 & 0.005 & 0.004 \\
\hline$\Delta \sigma_{V} X D F U x p$ banks in Spain & 0.002 & 0.006 & 0.030 & 0.023 \\
\hline Corruption perception index (10-CPI) & 0.006 & 0.002 & 0.028 & 0.019 \\
\hline Market volatility $($ VIX) & 0.014 & 0.030 & 0.016 & 0.008 \\
\hline \multicolumn{5}{|c|}{ Test of the differences in the selection equation between Portugal and Ireland } \\
\hline$\sigma_{V}$ & 0.004 & 0.003 & 0.003 & 0.002 \\
\hline Size (log total assets) & 0.002 & 0.001 & 0.002 & 0.010 \\
\hline Corruption perception index (10-CPI) & 0.006 & 0.023 & 0.003 & 0.003 \\
\hline \multicolumn{5}{|c|}{ Test of the differences between Portugal and Spain } \\
\hline$\Delta \sigma_{V}$ & 0.326 & 0.286 & 0.015 & 0.039 \\
\hline Lambda (Mills ratio) & 0.003 & 0.004 & 0.042 & 0.026 \\
\hline Size (log total assets) & 0.002 & 0.002 & 0.123 & 0.086 \\
\hline$\Delta \sigma_{V} \times D F U x p$ banks in Italy & 0.024 & 0.027 & 0.006 & 0.007 \\
\hline Corruption perception index $(10-\mathrm{CPI})$ & 0.028 & 0.031 & 0.001 & 0.001 \\
\hline Market volatility (VIX) & 0.263 & 0.385 & 0.698 & 0.582 \\
\hline Size (log total assets) & 0.003 & 0.004 & 0.638 & 0.125 \\
\hline Corruption perception index (10-CPI) & 0.005 & 0.042 & 0.029 & 0.045 \\
\hline \multicolumn{5}{|c|}{ Test of the differences between Portugal and Italy } \\
\hline$\Delta \sigma_{V}$ & 0.005 & 0.004 & 0.035 & 0.028 \\
\hline Size (log total assets) & 0.008 & 0.005 & 0.006 & 0.004 \\
\hline$\Delta \sigma_{V} X D F U x p$ banks in Spain & 0.003 & 0.002 & 0.010 & 0.013 \\
\hline Corruption perception index (10-CPI) & 0.235 & 0.094 & 0.012 & 0.014 \\
\hline Market volatility (VIX) & 0.131 & 0.122 & 0.193 & 0.281 \\
\hline \multicolumn{5}{|c|}{ Test of the differences in the selection equation between Portugal and Italy } \\
\hline$\Delta \sigma_{V}$ & 0.002 & 0.003 & 0.003 & 0.002 \\
\hline Size (log total assets) & 0.008 & 0.032 & 0.002 & 0.001 \\
\hline Corruption perception index (10-CPI) & 0.005 & 0.004 & 0.004 & 0.003 \\
\hline \multicolumn{5}{|c|}{ Test of the differences between Ireland and Spain } \\
\hline$\Delta \sigma_{V}$ & 0.043 & 0.034 & 0.013 & 0.011 \\
\hline Size (log total assets) & 0.006 & 0.005 & 0.003 & 0.002 \\
\hline$\Delta \sigma_{V} \times D F U x p$ banks in Spain & 0.004 & 0.002 & 0.008 & 0.010 \\
\hline \multicolumn{5}{|c|}{ Test of the differences in the selection equation between Ireland and Spain } \\
\hline$\Delta \sigma_{V}$ & 0.005 & 0.006 & 0.002 & 0.002 \\
\hline Size (log total assets) & 0.001 & 0.001 & 0.003 & 0.002 \\
\hline Corruption perception index $(10-\mathrm{CPI})$ & 0.002 & 0.001 & 0.001 & 0.001 \\
\hline \multicolumn{5}{|c|}{ Test of the differences between Ireland and Italy } \\
\hline$\Delta \sigma_{V}$ & 0.006 & 0.008 & 0.013 & 0.008 \\
\hline Size (log total assets) & 0.013 & 0.016 & 0.005 & 0.003 \\
\hline$\Delta \sigma_{V} \times D F U x p$ banks in Spain & 0.026 & 0.031 & 0.007 & 0.009 \\
\hline Corruption perception index (10-CPI) & 0.018 & 0.014 & 0.012 & 0.013 \\
\hline Market volatility $($ VIX) & 0.026 & 0.034 & 0.015 & 0.019 \\
\hline \multicolumn{5}{|c|}{ Test of the differences in the selection equation between Ireland and Italy } \\
\hline$\Delta \sigma_{V}$ & 0.001 & 0.001 & 0.001 & 0.001 \\
\hline Size (log total assets) & 0.001 & 0.001 & 0.010 & 0.028 \\
\hline Corruption perception index (10-CPI) & 0.003 & 0.002 & 0.007 & 0.006 \\
\hline \multicolumn{5}{|c|}{ Test of the differences between Spain and Italy } \\
\hline$\Delta \sigma_{V}$ & 0.026 & 0.031 & 0.008 & 0.029 \\
\hline Size (log total assets) & 0.005 & 0.008 & 0.004 & 0.003 \\
\hline$\Delta \sigma_{V} \times D F U x p$ banks in Spain & 0.236 & 0.184 & 0.026 & 0.021 \\
\hline Corruption perception index (10-CPI) & 0.013 & 0.010 & 0.236 & 0.208 \\
\hline Market volatility $(\mathrm{VIX})$ & 0.650 & 0.635 & 0.336 & 0.381 \\
\hline \multicolumn{5}{|c|}{ Test of the differences in the selection equation between Spain and Italy } \\
\hline$\Delta \sigma_{V}$ & 0.001 & 0.001 & 0.001 & 0.001 \\
\hline Size (log total assets) & 0.089 & 0.136 & 0.007 & 0.015 \\
\hline Corruption perception index (10-CPI) & 0.012 & 0.009 & 0.003 & 0.002 \\
\hline
\end{tabular}


TABLE 11

TESTS OF COEFFICIENT DIFFERENCES BETWEEN DMS MODELS ESTIMATED FOR PRECRISIS YEARS (2003-2006) AND CRISIS YEARS (2007-2008): DFU BANKS RECEIVING STATE AID IN PORTUGAL, IRELAND, SPAIN AND ITALY VS. DFU BANKS IN THE EUROPEAN SAMPLE

The table show the p-values of the tests for coefficient differences as well as the F-test of the overall differences between the subsamples

\begin{tabular}{|c|c|c|c|c|}
\hline \multicolumn{5}{|c|}{ Portugal, Ireland, Spain and Italy vs. European sample (PRECRISIS) } \\
\hline & RV & $\mathrm{ML}$ & RV & $\mathrm{ML}$ \\
\hline$\Delta \sigma_{\mathrm{V}}$ & 0.014 & 0.017 & 0.005 & 0.006 \\
\hline Size (log total assets) & 0.009 & 0.008 & 0.128 & 0.682 \\
\hline$\Delta \sigma_{V} X D F U$ banks & 0.013 & 0.010 & 0.016 & 0.014 \\
\hline $\begin{array}{l}\text { Corruption perception index } \\
(10-\mathrm{CPI})\end{array}$ & 0.143 & 0.138 & 0.231 & 0.228 \\
\hline Market volatility (VIX) & - & - & - & - \\
\hline Overall coefficients F-test & 0.006 & 0.010 & 0.011 & 0.013 \\
\hline \multicolumn{5}{|c|}{ Portugal, Ireland, Spain and Italy vs. European sample (CRISIS) } \\
\hline & RV & ML & $\mathrm{RV}$ & ML \\
\hline$\Delta \sigma_{V}$ & 0.005 & 0.004 & 0.005 & 0.006 \\
\hline Size (log total assets) & 0.008 & 0.010 & 0.014 & 0.026 \\
\hline$\Delta \sigma_{V} X D F U$ banks & 0.403 & 0.396 & 0.002 & 0.012 \\
\hline $\begin{array}{l}\text { Corruption perception index } \\
(10-C P I)\end{array}$ & 0.010 & 0.013 & 0.036 & 0.054 \\
\hline Market volatility (VIX) & - & - & - & - \\
\hline Overall coefficients F-test & 0.013 & 0.011 & 0.014 & 0.016 \\
\hline
\end{tabular}

